\title{
The magnesium isotope record of cave carbonate archives
}

\author{
S. Riechelmann ${ }^{1}$, D. Buhl ${ }^{1}$, A. Schröder-Ritzrau ${ }^{2}$, D. F. C. Riechelmann ${ }^{3}$, D. K. Richter ${ }^{1}$, H. B. Vonhof ${ }^{4}$, \\ J. A. Wassenburg ${ }^{1}$, A. Geske ${ }^{1}$, C. Spött ${ }^{5}$, and A. Immenhauser ${ }^{1}$ \\ ${ }^{1}$ Ruhr-University Bochum, Institute for Geology, Mineralogy and Geophysics, Universitätsstraße 150, \\ 44801 Bochum, Germany \\ ${ }^{2}$ Heidelberg Academy of Sciences, Im Neuenheimer Feld 229, 69120 Heidelberg, Germany \\ ${ }^{3}$ Johannes Gutenberg University Mainz, Institute of Geography, Johann-Joachim-Becher-Weg 21, 55099 Mainz, Germany \\ ${ }^{4}$ Faculty of Earth and Life Sciences, Vrije Universiteit Amsterdam, De Boelelaan 1085, 1081 HV, \\ Amsterdam, The Netherlands \\ ${ }^{5}$ Leopold-Franzens-University Innsbruck, Institute for Geology and Palaeontology, Innrain 52, 6020 Innsbruck, Austria
}

Correspondence to: S. Riechelmann (sylvia.riechelmann@rub.de)

Received: 30 April 2012 - Published in Clim. Past Discuss.: 22 May 2012

Revised: 12 October 2012 - Accepted: 27 October 2012 - Published: 20 November 2012

\begin{abstract}
Here we explore the potential of magnesium $\left(\delta^{26} \mathrm{Mg}\right)$ isotope time-series data as continental climate proxies in speleothem calcite archives. For this purpose, a total of six Pleistocene and Holocene stalagmites from caves in Germany, Morocco and Peru and two flowstones from a cave in Austria were investigated. These caves represent the semiarid to arid (Morocco), the warm-temperate (Germany), the equatorial-humid (Peru) and the cold-humid (Austria) climate zones. Changes in the calcite magnesium isotope signature with time are compared against carbon and oxygen isotope records from these speleothems. Similar to other proxies, the non-trivial interaction of a number of environmental, equilibrium and disequilibrium processes governs the $\delta^{26} \mathrm{Mg}$ fractionation in continental settings. These include the different sources of magnesium isotopes such as rainwater or snow as well as soil and host rock, soil zone biogenic activity, shifts in silicate versus carbonate weathering ratios and residence time of water in the soil and karst zone. Pleistocene stalagmites from Morocco show the lowest mean $\delta^{26} \mathrm{Mg}$ values (GDA: $-4.26 \pm 0.07 \%$ and HK3: $-4.17 \pm 0.15 \%$ ) , and the data are well explained in terms of changes in aridity over time. The Pleistocene to Holocene stalagmites from Peru show the highest mean value of all stalagmites (NC-A and NC-B $\delta^{26} \mathrm{Mg}:-3.96 \pm 0.04 \%$ ) but only minor variations in $\mathrm{Mg}$-isotope composition, which is consistent with the rather stable equatorial climate at this site. Holocene stalagmites from Germany (AH-1 mean $\delta^{26} \mathrm{Mg}:-4.01 \pm 0.07 \%$; BU 4 mean $\delta^{26} \mathrm{Mg}$ : $-4.20 \pm 0.10 \%$ ) suggest changes in outside
\end{abstract}

air temperature was the principal driver rather than rainfall amount. The alpine Pleistocene flowstones from Austria (SPA 52: $-3.00 \pm 0.73 \%$; SPA 59: $-3.70 \pm 0.43 \%$ ) are affected by glacial versus interglacial climate change with outside air temperature affecting soil zone activity and weathering balance. Several $\delta^{26} \mathrm{Mg}$ values of the Austrian and two $\delta^{26} \mathrm{Mg}$ values of the German speleothems are shifted to higher values due to sampling in detrital layers (Mg-bearing clay minerals) of the speleothems. The data and their interpretation shown here highlight the potential but also the limitations of the magnesium isotope proxy applied in continental climate research. An obvious potential lies in its sensitivity for even subtle changes in soil-zone parameters, a hitherto rather poorly understood but extremely important component in cave archive research. Limitations are most obvious in the low resolution and high sample amount needed for analysis. Future research should focus on experimental and conceptual aspects including quantitative and well-calibrated leaching and precipitation experiments.

\section{Introduction}

Carbon and oxygen isotope ratios as well as trace elemental abundances are widely used proxy data from speleothem archives (e.g. Genty and Massault, 1999; Spötl et al., 2002; Lachniet et al., 2004; Cruz Jr. et al., 2007; Fairchild and McMillian, 2007; Rudzka et al., 2011). The factors that 
control speleothem geochemistry include ambient environmental parameters (Baker and Genty, 1998; Spötl et al., 2005; Baldini et al., 2008), carbonate mineralogy (Frisia et al., 2000, 2002; Frisia and Borsato, 2010; Wassenburg et al., 2012), as well as processes and conditions in the aquifer (Tooth and Fairchild, 2003; Miorandi et al., 2010; Sherwin and Baldini, 2011) and equilibrium and disequilibrium stable isotope fractionation during carbonate precipitation in the cave (White, 2004; Tremaine et al., 2011; Riechelmann et al., 2012a).

Despite significant advances in field studies (Spötl et al., 2005; Asrat et al., 2008; Verheyden et al., 2008; Riechelmann et al., 2011), including experimental (Huang and Fairchild, 2001; Day and Henderson, 2011; Polag et al., 2010) and numerical (Mühlinghaus et al., 2007; Scholz et al., 2009; DePaolo, 2011; Dreybrodt and Scholz, 2011) work, several parameters that affect proxy data remain difficult to constrain. In this respect, the validation of proxy data from individual coeval stalagmites within a given cave (Dorale et al., 1998; Vollweiler et al., 2006; Fohlmeister et al., 2012) and between different caves (Williams et al., 2004; Mangini et al., 2005) is a key issue.

More recently, it has been proposed that multi-proxy studies including novel approaches such as fluid inclusions, noble gases, clumped isotopes and non-traditional isotope systems (Kluge et al., 2008; Scheidegger et al., 2008; Immenhauser et al., 2010; Daëron et al., 2011; Reynard et al., 2011; Kluge et al., 2012) may provide valuable information and complement more traditional proxy data. Amongst these more recently established proxies are $\mathrm{Mg}$ isotope $\left(\delta^{26} \mathrm{Mg}\right)$ data. Previous work dealing with $\mathrm{Mg}$ isotope fractionation in Earth surface environments includes investigations from carbonate archives and field and laboratory precipitation experiments. Data available in the literature include $\delta^{26} \mathrm{Mg}$ values from rain, snow, riverine, soil and drip water as well as host rock and cave carbonates and soil and cave silicate data (Galy et al., 2002; Young and Galy, 2004; de Villiers et al., 2005; Tipper et al., 2006b, 2008, 2010; Buhl et al., 2007; Brenot et al., 2008; Immenhauser et al., 2010; Pokrovsky et al., 2011; Riechelmann et al., 2012b). Nevertheless, with the exception of the preliminary work shown in Buhl et al. (2007), a critical application of the above-cited work to speleothem time series is lacking.

Here we report on the potential and limitations of $\mathrm{Mg}$ isotope time series proxy data interpretation from eight speleothems collected in six caves on three different continents. The goals of this study are to review parameters known to affect $\mathrm{Mg}$ isotope fractionation between land surface and cave carbonate deposition and to apply these findings to all available $\delta^{26} \mathrm{Mg}$ data sets from Pleistocene/Holocene speleothems and flowstones.

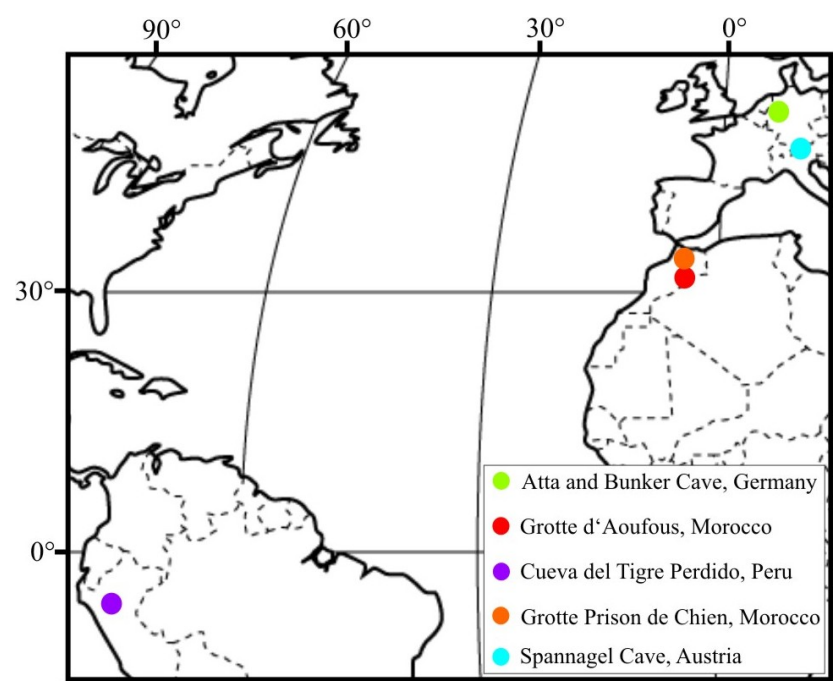

Fig. 1. Map with the locations of studied caves. Atta and Bunker Cave (Germany) are represented by a single green dot.

\section{Case settings}

This study uses $\mathrm{Mg}$ isotope data from six stalagmites and two flowstones. These include two stalagmites from Germany (Atta Cave and Bunker Cave), two stalagmites from Morocco (Grotte d'Aoufous and Grotte Prison de Chien), two stalagmites from Peru (Cueva del Tigre Perdido) and two flowstones from Austria (Spannagel Cave). The reader is referred to Fig. 1 and Table 1 for detailed information regarding cave parameters and speleothems investigated.

\section{Magnesium isotope analyses}

Powder subsamples from longitudinally cut stalagmites and flowstones were dissolved in $6 \mathrm{M} \mathrm{HCl}$. The solution was dried and redissolved with $250 \mu \mathrm{l}$ of a 1:1 mixture of $\mathrm{HNO}_{3}$ $(65 \%): \mathrm{H}_{2} \mathrm{O}_{2}(31 \%)$. Subsequently, the solution was evaporated and again redissolved in $1.25 \mathrm{M} \mathrm{HCl}$. The $\mathrm{Mg}$-bearing fraction was extracted by using ion-exchange columns (BioRad ion exchange resin AG50 W-X12, 200 to 400 mesh), evaporated to dryness and a $500 \mathrm{ppb} \mathrm{Mg}$-solution (in $3.5 \%$ $\mathrm{HNO}_{3}$ ) was prepared. The samples were analyzed with a Thermo Fisher Scientific Neptune MC-ICP-MS using DSM3 standard solution. The external precision was determined by measuring the mono-elemental solution Cambridge 1 against DSM3 standard solution repeatedly $\left(n=89, \delta^{25} \mathrm{Mg}\right.$ : $-1.34 \pm 0.03 \%$ o $2 \sigma$ and $\delta^{26} \mathrm{Mg}:-2.58 \pm 0.06 \%$ o $\left.2 \sigma\right)$. For details of the analytical procedure, refer to Immenhauser et al. (2010).

The stalagmite AH-1 (Atta Cave) provided material that was tested for the impact of fluid inclusions in the calcite fabric on the $\delta^{26} \mathrm{Mg}$ value of the bulk sample. The sample was taken because it contains numerous fluid inclusions. Calcite samples from this stalagmite were extracted and half of each 


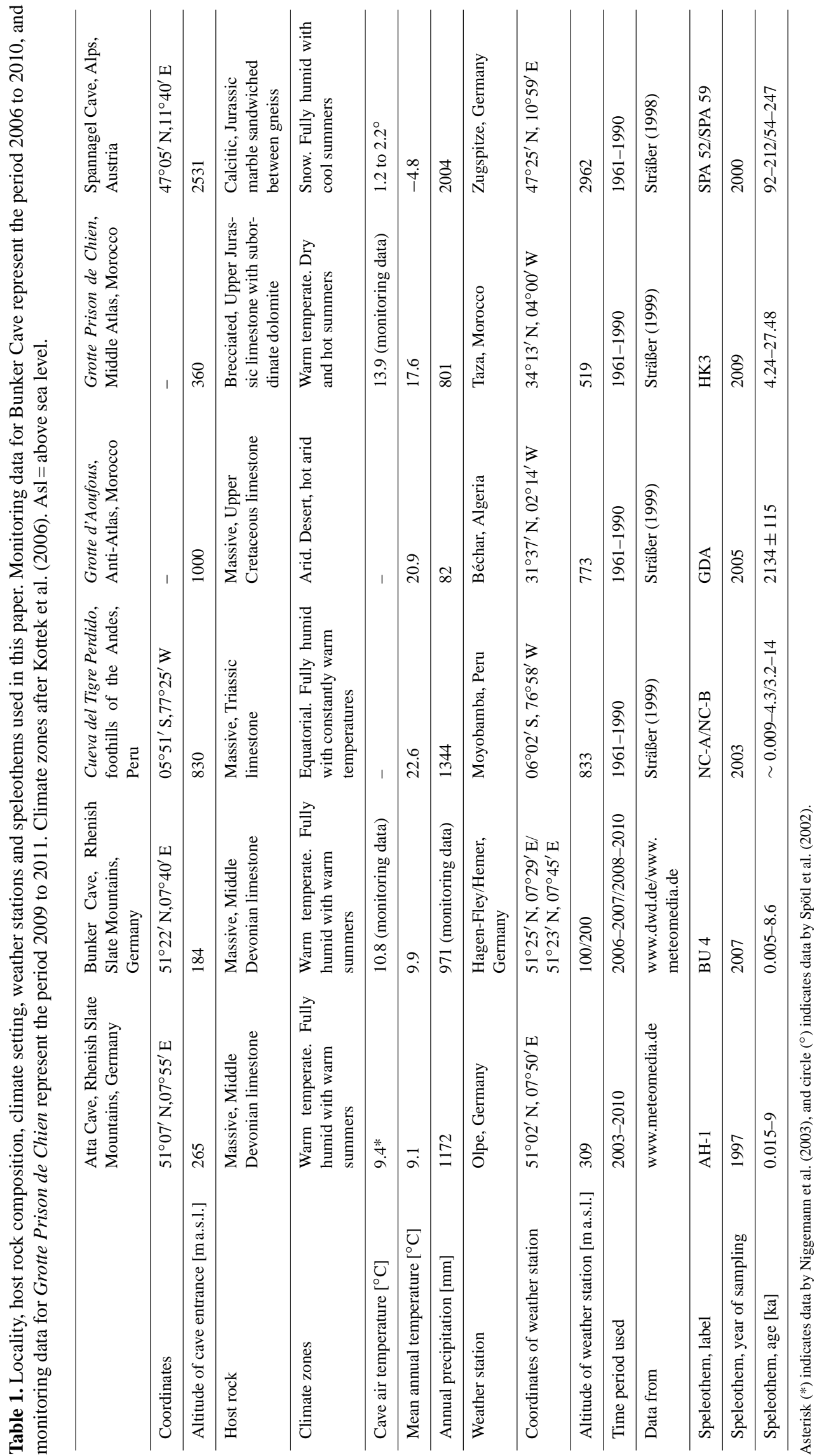


sample powdered in acetone to remove the fluid inclusions and subsequently analysed for their magnesium isotope signature. Aliquots of non-treated samples were analysed too and results were compared.

Layers of detrital material were observed in the stalagmites BU 4 and AH-1 as well as in the flowstones SPA 52 and SPA 59. Besides quartz, feldspar and mica, detrital layers contain high amounts of clay minerals that are in part dissolved in $6 \mathrm{M} \mathrm{HCl}$ especially during heating (Madejová et al., 1998; Komadel and Madejová, 2006). It seems thus likely that clay minerals with higher $\delta^{26} \mathrm{Mg}$ values were also analysed in parallel with the $\mathrm{CaCO}_{3}$, which leads to more elevated $\delta^{26} \mathrm{Mg}$ values. Samples collected from these layers are indicated by red triangles in the corresponding figures.

\section{Environmental, equilibrium and disequilibrium factors affecting the $\mathrm{Mg}$ isotope fractionation in continental karst systems}

Environmental, equilibrium and disequilibrium factors affecting $\mathrm{Mg}$ isotope fractionation in Earth surface systems have been described in Galy et al. (2002), Young and Galy (2004), de Villiers et al. (2005), Tipper et al. (2006b, 2008, 2010), Buhl et al. (2007), Brenot et al. (2008), Immenhauser et al. (2010), Pokrovsky et al. (2011) and Riechelmann et al. (2012b). Considering the published work, the following parameters are of significance for the interpretation of speleothem $\delta^{26} \mathrm{Mg}$ time-series: (i) $\delta^{26} \mathrm{Mg}$ signature of all involved $\mathrm{Mg}$ sources - rainwater, soil cover (silicates) and host rock (limestone or dolostone); (ii) the biogenic activity of the soil zone controlled mainly by water availability and air temperature; (iii) the balance between the silicate (Mgbearing clay minerals) and carbonate weathering ratio in the soil zone. (The soil commonly contains clays with higher $\delta^{26} \mathrm{Mg}$ values and clasts of diagenetically stabilised carbonate host rock or authigenic carbonate phases both with lower $\delta^{26} \mathrm{Mg}$ values); (iv) the residence time of soil and karst water in the aquifer above the cave and (v) carbonate precipitation rates in the cave environment.

In contrast, even when considering the maximum range of Pleistocene, to recent air temperature change in caves in Germany (ca. 9 to $10^{\circ} \mathrm{C}$; Richter et al., 2010), temperaturerelated $\mathrm{Mg}$ isotope fractionation during calcite precipitation is a minor factor with experimental data suggesting a $\delta^{26} \mathrm{Mg}$ dependency of $0.011 \%$ per degree celsius from 4 to $45^{\circ} \mathrm{C}$ (Li et al., 2012) and $0.02 \%$ o/AMU/ $/{ }^{\circ} \mathrm{C}$ between 4 and $18^{\circ} \mathrm{C}$ (Galy et al., 2002).

Rainwater becomes progressively ${ }^{26} \mathrm{Mg}$-enriched with increasing distance to the marine aerosol source and may reveal temperature-related fractionation patterns; i.e. snow is ${ }^{26} \mathrm{Mg}$ depleted compared to rain (Tipper et al., 2010; Riechelmann et al., 2012b), but the existing data set is perhaps too limited to draw solid conclusions. Tipper et al. (2012) stated that the input of $\mathrm{Mg}$ from the rainwater (dust and aerosols)

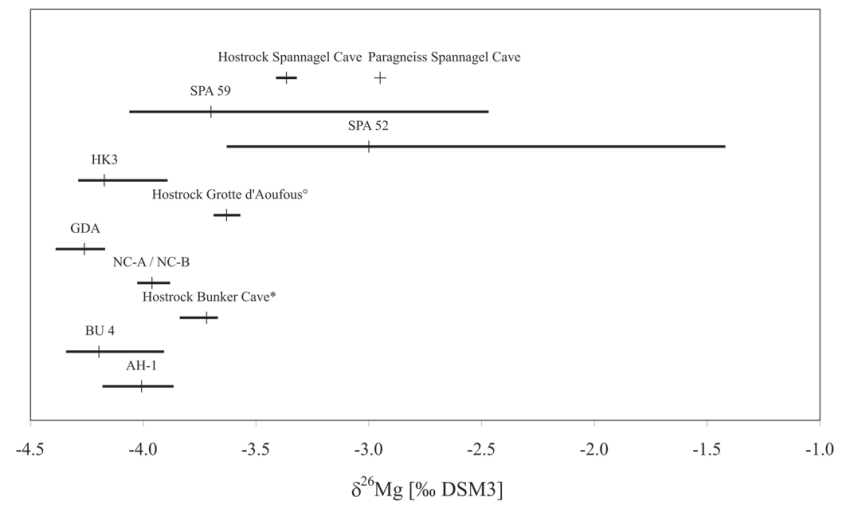

Fig. 2. Overview of Mg-isotope data of the studied speleothems and host rock. Mean value is indicated by thin vertical line; width of horizontal bars indicates data range. Asterisk (*) indicates data from Immenhauser et al. (2010), and circle $\left(^{\circ}\right)$ indicates data from Buhl et al. (2007).

to river water is very small $(\leq 0.6 \%)$. Commonly, rainwater has a $\delta^{26} \mathrm{Mg}$ value that is very similar to that of seawater and, hence, a correction of the river water $\delta^{26} \mathrm{Mg}$ value would shift this value by less than the analytical uncertainty. The $\delta^{26} \mathrm{Mg}$ value of dolostone ( -2.2 to $-1.1 \%$; $\mathrm{Li}$ et al., 2012) is in general higher than that of limestone $(-5.3$ to $-1 \%$; Li et al., 2012), whilst silicate rocks and clay minerals have the highest $\delta^{26} \mathrm{Mg}$ values $(-1.1$ to $+0.1 \%$; Immenhauser et al., 2010).

Biological Mg isotope fractionation by plants and soil microorganisms affects the Mg-isotope composition of the soil water in variable degrees depending on the amount of $\mathrm{Mg}$ involved and plant and microbial metabolism (Tipper et al., 2010; Riechelmann et al., 2012b). Clearly, under warmer and wetter conditions, soil activity is increased (Harper et al., 2005) and enhanced plant growth induces a stronger biological fractionation. Grass, for example, is ${ }^{26} \mathrm{Mg}$-enriched in comparison to its rainwater source (Tipper et al., 2010). The weathering of Mg-bearing clay minerals in the soil is relatively higher during warmer and drier climate conditions compared to carbonate weathering, which is always dominant but particularly under more humid and cooler conditions (Tipper et al., 2006a, b; Egli et al., 2008; Buhl et al., 2007; Immenhauser et al., 2010; Maher, 2010). The weathering signal of silicates in the soil is recorded in the Mg-isotope composition of soil water. The same trend was observed for ${ }^{26} \mathrm{Mg}$-depleted cave drip water compared to soil water. In summary of these considerations, it was suggested that carbonate versus silicate weathering ratios are recorded in the speleothem Mg isotope record (Riechelmann et al., 2012b).

Prolonged water residence times in the karst aquifer lead to lower $\delta^{26} \mathrm{Mg}$ values in the drip waters. This is because the mixing time between younger, newly infiltrating ${ }^{26} \mathrm{Mg}$-enriched water and older ${ }^{26} \mathrm{Mg}$-depleted, limestoneequilibrated aquifer water is longer. The result is an overall 


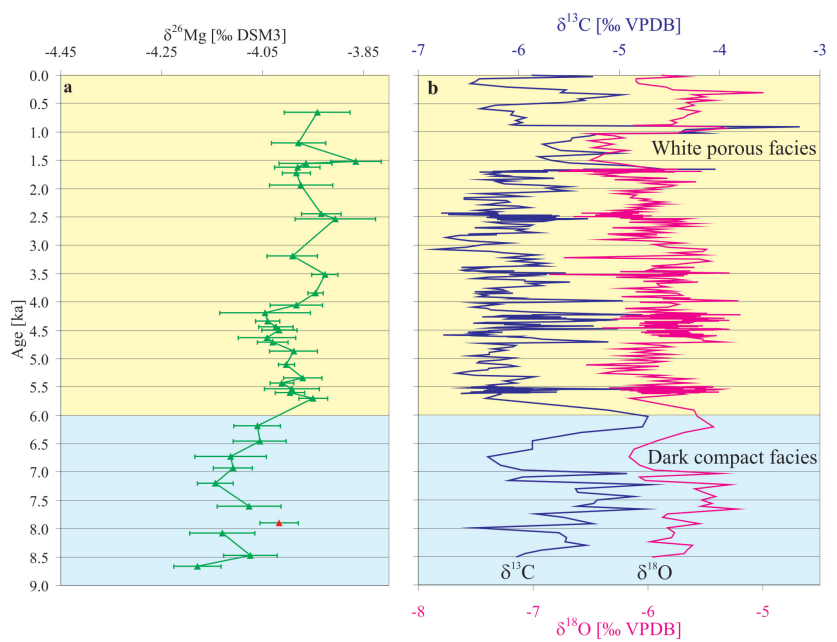

Fig. 3. Magnesium, carbon and oxygen isotope data of the stalagmite AH-1 from Atta Cave, Germany. (a) Mg-isotope data plotted against age in ka BP using the StalAge model of Scholz and Hoffmann (2011). Red triangle indicates sample taken in a detritus layer. (b) Carbon (dark blue) and oxygen (magenta) isotope data plotted against age in ka BP (data from Niggemann et al., 2003). Portions of the speleothem characterized by a dark compact facies are shown in blue; those characterized by a white porous facies are shown in yellow.

${ }^{26} \mathrm{Mg}$-depleted drip water. For shorter water residence times, the opposite pattern is found (Riechelmann et al., 2012b). Based on laboratory precipitation experiments (Immenhauser et al., 2010), lower carbonate precipitation rates lead to lower $\delta^{26} \mathrm{Mg}$ values and vice versa. This, however, refers to experimental fluids that are considerably more saturated than those commonly found in natural cave environments and to precipitation rates (50 to $630 \mu \mathrm{molh} \mathrm{h}^{-1}$ ) that exceed those of most natural speleothems (range of 0.0008 to $9.94 \mu \mathrm{mol} \mathrm{h}^{-1} / 0.1$ to $1140 \mu \mathrm{m} \mathrm{yr}^{-1}$ for speleothems AH1, BU 4, NC-A, NC-B, SPA 52 and SPA 59 from caves in Germany, Peru and Austria). A statistically significant impact of experimental precipitation rate on calcite $\delta^{26} \mathrm{Mg}$ values is found at rates exceeding $200 \mu \mathrm{mol} \mathrm{h}^{-1}$. Therefore, the direct applicability of the precipitation experiment data shown in Immenhauser et al. (2010) to natural systems is at present unclear.

\section{Speleothem geochemistry: results}

Carbon and oxygen isotope time series data as well as U-Th age data shown in Figs. 3 and 5-10 are published in Niggemann et al. (2003), Holzkämper et al. (2005), Buhl et al. (2007), Spötl et al. (2007), van Breukelen et al. (2008), van Breukelen (2009), Wassenburg et al. (2012) and Fohlmeister et al. (2012). Magnesium isotope data of the stalagmites and flowstones are shown in Tables 2 and 3

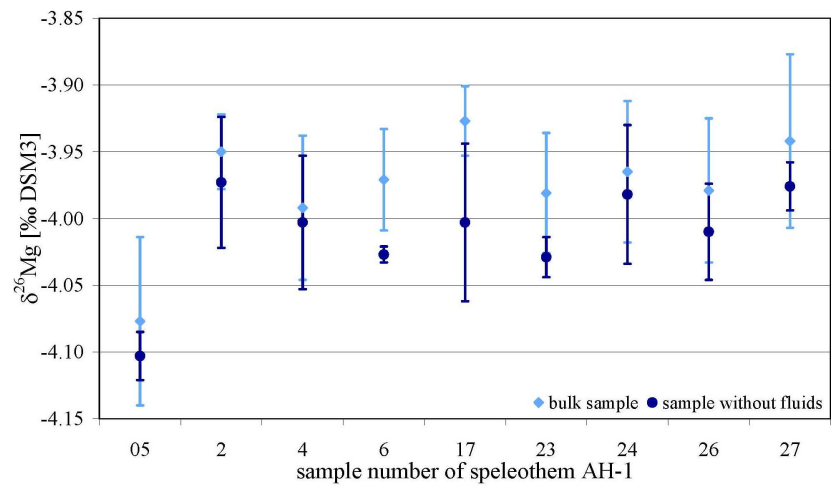

Fig. 4. Magnesium isotope composition of aliquots of samples from stalagmite AH-1. Dark blue indicates crushed samples in order to remove fluid inclusions whilst light blue indicates bulk samples. Note systematic offset.

and Fig. 2. Below, the main geochemical characteristics are summarised for each analysed speleothem.

Moroccan stalagmites GDA and HK3 and stalagmite BU 4 from Germany yielded the lowest mean $\delta^{26} \mathrm{Mg}$ values, whilst flowstones SPA 52 and SPA 59 from Austria have the highest mean $\delta^{26} \mathrm{Mg}$ values. Stalagmite $\mathrm{AH}-1$ from Germany and the Peruvian stalagmites NC-A and NC-B yielded intermediate mean $\delta^{26} \mathrm{Mg}$ values (Fig. 2). The flowstones SPA 52 and SPA 59 show the highest variations in their Mg-isotope composition. In contrast, stalagmite $\delta^{26} \mathrm{Mg}$ is less variable. Stalagmite HK3 (Morocco) and stalagmite BU 4 (Germany) show the highest amplitudes in $\delta^{26} \mathrm{Mg}$ values, whilst stalagmites NC-A and NC-B (Peru) reveal the lowest degree of variability and therefore the smallest $\Delta^{26} \mathrm{Mg}$ (Table 2). Stalagmites AH-1 (Germany) and GDA (Morocco) show intermediate variations (Fig. 2).

\subsection{Stalagmite AH-1, Atta Cave, Germany}

Holocene to recent (1997 AD) stalagmite AH-1 $\delta^{26} \mathrm{Mg}$ values range from $-4.18 \pm 0.05 \%$ o to $-3.86 \pm 0.03 \%$ with a mean of $-4.01 \pm 0.07 \%$ (Figs. 2 and 3a, Tables 2 and 3). Stalagmite AH-1 yielded overall lower $\delta^{26} \mathrm{Mg}$ values between 9.0 and $6.0 \mathrm{ka} \mathrm{BP}$ and higher $\delta^{26} \mathrm{Mg}$ values between 6.0 and $0.7 \mathrm{ka} \mathrm{BP}$. Between 6.0 and $4.2 \mathrm{ka} \mathrm{BP}$, a trend to lower $\delta^{26} \mathrm{Mg}$ values is observed; between 9.0 to $6.0 \mathrm{ka} \mathrm{BP}$ and 4.2 to $0.7 \mathrm{ka} \mathrm{BP}$, a weak trend of higher $\delta^{26} \mathrm{Mg}$ values and a higher overall variability is found. The lowest $\delta^{26} \mathrm{Mg}$ value is found at $8.7 \mathrm{ka} \mathrm{BP}$. A higher $\delta^{26} \mathrm{Mg}$ value at $7.9 \mathrm{ka}$ $\mathrm{BP}$ coincides with a detritus layer. Between 4.2 to $3.5 \mathrm{ka} \mathrm{BP}$, a trend to higher values is found. At $3.2 \mathrm{ka} \mathrm{BP}$, the $\delta^{26} \mathrm{Mg}$ value becomes slightly lower, whilst subsequently the value is again more ${ }^{26} \mathrm{Mg}$-enriched at $2.5 \mathrm{ka} \mathrm{BP}$. Between 2.5 and $1.6 \mathrm{ka} \mathrm{BP} \delta^{26} \mathrm{Mg}$ values decrease again and then increase between 1.6 and $1.5 \mathrm{ka}$ BP. At $1.5 \mathrm{ka}$ BP the highest $\delta^{26} \mathrm{Mg}$ value is present. At $1.2 \mathrm{ka} \mathrm{BP}, \delta^{26} \mathrm{Mg}$ shows again a lower 
Table 2. Magnesium-isotope values of all speleothem samples. Repeated analyses are marked "wh" and mean values are indicated "mean". $\Delta^{25} \mathrm{Mg}$ ' data were calculated using the equations of Young and Galy (2004) in order to document the accuracy of analytical results. AH-1: 36 samples (July to August 2007), BU 4: 23 samples (February to March 2011), NC-A/NC-B: 3/6 samples (January to February 2008), GDA: 18 samples (June 2006), HK3: 6 samples (June 2011) and SPA 52/SPA 59: 8/12 samples (October 2009 to January 2010).

\begin{tabular}{|c|c|c|c|c|c|c|}
\hline $\begin{array}{l}\text { speleo- } \\
\text { them }\end{array}$ & sample & $\begin{array}{r}\delta^{25} \mathrm{Mg} \\
{[\% 0} \\
\text { DSM3] }\end{array}$ & $\pm 2 \sigma$ & $\begin{array}{r}\delta^{26} \mathrm{Mg} \\
{[\% \circ} \\
\text { DSM3] }\end{array}$ & $\pm 2 \sigma$ & $\Delta^{25} \mathrm{Mg}$ \\
\hline AH-1 & 09 & -2.17 & 0.02 & -4.18 & 0.05 & 0.01 \\
\hline AH-1 & 08 & -2.13 & 0.01 & -4.07 & 0.05 & -0.01 \\
\hline AH-1 & 07 & -2.14 & 0.02 & -4.13 & 0.07 & 0.02 \\
\hline AH-1 & 06 & -2.09 & 0.01 & -4.02 & 0.04 & 0.00 \\
\hline AH-1 & 05 & -2.11 & 0.02 & -4.08 & 0.06 & 0.01 \\
\hline AH-1 & 04 & -2.12 & 0.02 & -4.14 & 0.04 & 0.04 \\
\hline AH-1 & 03 & -2.14 & 0.02 & -4.11 & 0.04 & 0.01 \\
\hline AH-1 & 02 & -2.12 & 0.01 & -4.11 & 0.07 & 0.02 \\
\hline AH-1 & 01 & -2.10 & 0.01 & -4.06 & 0.05 & 0.02 \\
\hline AH-1 & 1 & -2.11 & 0.02 & -4.06 & 0.05 & 0.01 \\
\hline AH-1 & 2 & -2.05 & 0.02 & -3.95 & 0.03 & 0.01 \\
\hline AH-1 & 3 & -2.08 & 0.02 & -4.00 & 0.03 & 0.01 \\
\hline AH-1 & 4 & -2.07 & 0.03 & -3.99 & 0.05 & 0.01 \\
\hline AH-1 & 5 & -2.07 & 0.01 & -4.01 & 0.02 & 0.02 \\
\hline AH-1 & 6 & -2.07 & 0.02 & -3.97 & 0.04 & 0.01 \\
\hline AH-1 & 7 & -2.08 & 0.02 & -4.00 & 0.02 & 0.01 \\
\hline AH-1 & 8 & -2.07 & 0.02 & -3.99 & 0.05 & 0.01 \\
\hline AH-1 & 9 & -2.08 & 0.03 & -4.03 & 0.03 & 0.02 \\
\hline AH-1 & 10 & -2.08 & 0.03 & -4.04 & 0.06 & 0.02 \\
\hline $\mathrm{AH}-1$ & 11 & -2.09 & 0.03 & -4.02 & 0.04 & 0.00 \\
\hline $\mathrm{AH}-1$ & 12 & -2.08 & 0.02 & -4.02 & 0.03 & 0.02 \\
\hline $\mathrm{AH}-1$ & 13 & -2.10 & 0.02 & -4.04 & 0.02 & 0.01 \\
\hline $\mathrm{AH}-1$ & 14 & -2.10 & 0.04 & -4.07 & 0.09 & 0.02 \\
\hline $\mathrm{AH}-1$ & $14 \mathrm{wh}$ & -2.09 & 0.02 & -4.02 & 0.03 & 0.01 \\
\hline $\mathrm{AH}-1$ & 14 mean & -2.10 & 0.04 & -4.05 & 0.09 & 0.01 \\
\hline $\mathrm{AH}-1$ & 15 & -2.07 & 0.03 & -3.98 & 0.05 & 0.01 \\
\hline AH-1 & 16 & -2.07 & 0.02 & -3.95 & 0.02 & -0.01 \\
\hline AH-1 & 17 & -2.04 & 0.02 & -3.93 & 0.03 & 0.01 \\
\hline AH-1 & 18 & -2.10 & 0.01 & -4.02 & 0.04 & -0.01 \\
\hline AH-1 & 18 wh & -2.05 & 0.02 & -3.96 & 0.05 & 0.02 \\
\hline $\mathrm{AH}-1$ & 18 mean & -2.08 & 0.04 & -3.99 & 0.05 & 0.00 \\
\hline AH-1 & 19 & -2.02 & 0.03 & -3.89 & 0.08 & 0.00 \\
\hline AH-1 & 19 wh & -2.04 & 0.03 & -3.93 & 0.03 & 0.01 \\
\hline AH-1 & 19 mean & -2.03 & 0.03 & -3.91 & 0.08 & 0.01 \\
\hline AH-1 & 20 & -2.04 & 0.03 & -3.93 & 0.04 & 0.01 \\
\hline AH-1 & 21 & -2.06 & 0.02 & -3.97 & 0.06 & 0.01 \\
\hline AH-1 & 22 & -2.06 & 0.02 & -3.98 & 0.03 & 0.01 \\
\hline AH-1 & 23 & -2.06 & 0.02 & -3.98 & 0.05 & 0.02 \\
\hline AH-1 & 24 & -2.08 & 0.03 & -3.97 & 0.05 & -0.01 \\
\hline AH-1 & 25 & -2.00 & 0.02 & -3.87 & 0.05 & 0.02 \\
\hline AH-1 & $25 \mathrm{wh}$ & -1.99 & 0.02 & -3.86 & 0.03 & 0.02 \\
\hline AH-1 & 25 mean & -1.99 & 0.02 & -3.87 & 0.05 & 0.03 \\
\hline AH-1 & 26 & -2.06 & 0.02 & -3.98 & 0.05 & 0.02 \\
\hline AH-1 & 27 & -2.05 & 0.04 & -3.94 & 0.07 & 0.01 \\
\hline BU 4 & 0 & -2.09 & 0.02 & -4.02 & 0.02 & 0.01 \\
\hline BU 4 & 1 & -2.14 & 0.02 & -4.12 & 0.03 & 0.01 \\
\hline BU 4 & 2 & -2.23 & 0.02 & -4.29 & 0.06 & 0.00 \\
\hline BU 4 & 3 & -2.14 & 0.02 & -4.13 & 0.02 & 0.01 \\
\hline BU 4 & 4 & -2.24 & 0.03 & -4.29 & 0.04 & 0.00 \\
\hline BU 4 & 5 & -2.18 & 0.02 & -4.21 & 0.03 & 0.01 \\
\hline BU 4 & 6 & -2.01 & 0.02 & -3.91 & 0.05 & 0.03 \\
\hline BU 4 & 7 & -2.13 & 0.02 & -4.12 & 0.03 & 0.02 \\
\hline
\end{tabular}

Table 2. Continued.

\begin{tabular}{|c|c|c|c|c|c|c|}
\hline $\begin{array}{l}\text { speleo- } \\
\text { them }\end{array}$ & sample & $\begin{array}{r}\delta^{25} \mathrm{Mg} \\
{[\%} \\
\text { DSM3] }\end{array}$ & $\pm 2 \sigma$ & $\begin{array}{r}\delta^{26} \mathrm{Mg} \\
{[\%} \\
\text { DSM3] }\end{array}$ & $\pm 2 \sigma$ & $\Delta^{25} \mathrm{Mg}$ \\
\hline BU 4 & 8 & -2.17 & 0.02 & -4.18 & 0.03 & 0.01 \\
\hline BU 4 & 9 & -2.19 & 0.03 & -4.22 & 0.06 & 0.01 \\
\hline BU 4 & 10 & -2.24 & 0.02 & -4.32 & 0.02 & 0.01 \\
\hline BU 4 & 11 & -2.19 & 0.02 & -4.21 & 0.02 & 0.01 \\
\hline BU 4 & 12 & -2.22 & 0.01 & -4.26 & 0.03 & 0.00 \\
\hline BU 4 & 13 & -2.19 & 0.02 & -4.21 & 0.06 & 0.01 \\
\hline BU 4 & $13 \mathrm{~A}$ & -2.16 & 0.01 & -4.18 & 0.02 & 0.02 \\
\hline BU 4 & 14 & -2.20 & 0.01 & -4.24 & 0.02 & 0.01 \\
\hline BU 4 & $14 \mathrm{~A}$ & -2.17 & 0.02 & -4.17 & 0.05 & 0.01 \\
\hline BU 4 & 15 & -2.24 & 0.01 & -4.31 & 0.01 & 0.00 \\
\hline BU 4 & $15 \mathrm{~A}$ & -2.12 & 0.02 & -4.08 & 0.02 & 0.00 \\
\hline BU 4 & 16 & -2.19 & 0.02 & -4.22 & 0.02 & 0.01 \\
\hline BU 4 & $16 \mathrm{~A}$ & -2.26 & 0.06 & -4.34 & 0.07 & 0.00 \\
\hline BU 4 & 17 & -2.21 & 0.02 & -4.26 & 0.01 & 0.01 \\
\hline BU 4 & $17 \mathrm{~A}$ & -2.21 & 0.01 & -4.27 & 0.01 & 0.02 \\
\hline NC-A & $0-0.5 \mathrm{~cm}$ & -2.00 & 0.03 & -3.88 & 0.03 & 0.02 \\
\hline NC-A & $10-10.5 \mathrm{~cm}$ & -2.08 & 0.02 & -4.03 & 0.04 & 0.02 \\
\hline NC-A & $20-20.5 \mathrm{~cm}$ & -2.03 & 0.01 & -3.92 & 0.01 & 0.02 \\
\hline NC-B & $0.5-01 \mathrm{~cm}$ & -2.05 & 0.02 & -3.96 & 0.05 & 0.01 \\
\hline NC-B & $5-5.5 \mathrm{~cm}$ & -2.05 & 0.02 & -3.97 & 0.03 & 0.02 \\
\hline NC-B & $11.5-12 \mathrm{~cm}$ & -2.08 & 0.02 & -3.99 & 0.01 & 0.00 \\
\hline NC-B & $18.5-19 \mathrm{~cm}$ & -2.03 & 0.03 & -3.96 & 0.06 & 0.03 \\
\hline NC-B & $18.5-19 \mathrm{~cm}$ wh & -2.04 & 0.02 & -3.94 & 0.03 & 0.01 \\
\hline NC-B & $18.5-19 \mathrm{~cm}$ mean & -2.04 & 0.03 & -3.95 & 0.06 & 0.02 \\
\hline NC-B & $25.5-26 \mathrm{~cm}$ & -2.07 & 0.02 & -4.00 & 0.04 & 0.01 \\
\hline NC-B & $28.5-29 \mathrm{~cm}$ & -2.05 & 0.02 & -3.96 & 0.03 & 0.02 \\
\hline GDA & $\operatorname{pos} 3 / 4$ & -2.22 & 0.03 & -4.28 & 0.04 & 0.02 \\
\hline GDA & pos 5 & -2.24 & 0.02 & -4.33 & 0.04 & 0.01 \\
\hline GDA & pos 10 & -2.28 & 0.02 & -4.38 & 0.05 & 0.01 \\
\hline GDA & pos 17 & -2.27 & 0.02 & -4.39 & 0.02 & 0.01 \\
\hline GDA & pos $22 \mathrm{a}$ & -2.19 & 0.02 & -4.23 & 0.03 & 0.01 \\
\hline GDA & pos 25 & -2.21 & 0.02 & -4.26 & 0.04 & 0.01 \\
\hline GDA & pos 30 & -2.17 & 0.01 & -4.17 & 0.05 & 0.01 \\
\hline GDA & pos 37 & -2.20 & 0.02 & -4.23 & 0.06 & 0.01 \\
\hline GDA & pos 45 & -2.25 & 0.02 & -4.31 & 0.08 & 0.00 \\
\hline GDA & pos $14 / 15$ & -2.26 & 0.02 & -4.35 & 0.05 & 0.01 \\
\hline GDA & pos 20 & -2.23 & 0.03 & -4.26 & 0.04 & -0.01 \\
\hline GDA & pos 40 & -2.16 & 0.02 & -4.18 & 0.03 & 0.02 \\
\hline GDA & pos 33a & -2.19 & 0.01 & -4.22 & 0.01 & 0.02 \\
\hline GDA & pos $33 b$ & -2.18 & 0.01 & -4.20 & 0.03 & 0.01 \\
\hline GDA & pos $33 \mathrm{e}$ & -2.17 & 0.02 & -4.19 & 0.03 & 0.01 \\
\hline GDA & pos $33 d$ & -2.18 & 0.03 & -4.21 & 0.03 & 0.01 \\
\hline GDA & pos $33 f$ & -2.19 & 0.01 & -4.22 & 0.02 & 0.01 \\
\hline GDA & pos $33 c$ & -2.18 & 0.02 & -4.19 & 0.04 & 0.01 \\
\hline HK3 & CA24 & -2.02 & 0.03 & -3.89 & 0.06 & 0.01 \\
\hline HK3 & CA37 & -2.20 & 0.03 & -4.21 & 0.07 & -0.01 \\
\hline HK3 & CA41 & -2.23 & 0.01 & -4.29 & 0.02 & 0.00 \\
\hline HK3 & CA45 & -2.22 & 0.04 & -4.27 & 0.09 & 0.00 \\
\hline HK3 & CA63 & -2.23 & 0.02 & -4.26 & 0.04 & 0.00 \\
\hline HK3 & CA74 & -2.16 & 0.02 & -4.13 & 0.03 & -0.01 \\
\hline SPA 52 & $\mathrm{a}$ & -1.48 & 0.02 & -2.84 & 0.06 & 0.00 \\
\hline SPA 52 & b & -1.35 & 0.03 & -2.62 & 0.06 & 0.02 \\
\hline SPA 52 & $\mathrm{c}$ & -1.61 & 0.02 & -3.11 & 0.02 & 0.01 \\
\hline SPA 52 & $\mathrm{~g}$ & -1.8 & 0.02 & -3.47 & 0.04 & 0.01 \\
\hline SPA 52 & d & -1.72 & 0.03 & -3.33 & 0.02 & 0.02 \\
\hline SPA 52 & $\mathrm{~h}$ & -1.86 & 0.09 & -3.58 & 0.14 & 0.01 \\
\hline SPA 52 & $\mathrm{e}$ & -1.89 & 0.05 & -3.63 & 0.05 & 0.00 \\
\hline SPA 52 & f & -0.73 & 0.02 & -1.42 & 0.04 & 0.01 \\
\hline SPA 59 & a & -2.10 & 0.02 & -4.06 & 0.04 & 0.02 \\
\hline SPA 59 & aa & -1.96 & 0.04 & -3.80 & 0.07 & 0.02 \\
\hline SPA 59 & $a b$ & -2.05 & 0.03 & -3.97 & 0.02 & 0.02 \\
\hline SPA 59 & $\mathrm{ac}$ & -2.07 & 0.05 & -3.99 & 0.09 & 0.01 \\
\hline SPA 59 & ad & -1.96 & 0.03 & -3.80 & 0.04 & 0.02 \\
\hline SPA 59 & ae & -1.93 & 0.05 & -3.70 & 0.07 & 0.00 \\
\hline SPA 59 & $\mathrm{~b}$ & -1.29 & 0.03 & -2.47 & 0.05 & 0.00 \\
\hline SPA 59 & $\mathrm{c}$ & -2.06 & 0.02 & -3.97 & 0.07 & 0.01 \\
\hline SPA 59 & $\mathrm{~d}$ & -1.86 & 0.03 & -3.59 & 0.06 & 0.01 \\
\hline SPA 59 & da & -1.79 & 0.02 & -3.43 & 0.03 & 0.00 \\
\hline SPA 59 & $\mathrm{e}$ & -1.99 & 0.01 & -3.83 & 0.03 & 0.01 \\
\hline SPA 59 & $\mathrm{f}$ & -1.96 & 0.04 & -3.78 & 0.06 & 0.01 \\
\hline
\end{tabular}


Table 3. Mean Mg-isotope ratios, minimum and maximum values and $\Delta^{26} \mathrm{Mg}$ (difference between maximum and minimum value) of speleothems discussed here. Number of samples used for statistics varies between 6 and 36 .

\begin{tabular}{lrrrrrrr}
\hline$\delta^{26} \mathrm{Mg}$ & & & & & & & \\
[\%o DSM3] & AH-1 & BU 4 & NC-A/NC-B & GDA & HK3 & SPA 52 & SPA 59 \\
\hline mean & $-4.01 \pm 0.07$ & $-4.20 \pm 0.10$ & $-3.96 \pm 0.04$ & $-4.26 \pm 0.07$ & $-4.17 \pm 0.15$ & $-3.00 \pm 0.73$ & $-3.70 \pm 0.43$ \\
$\min$ & $-4.18 \pm 0.05$ & $-4.34 \pm 0.07$ & $-4.03 \pm 0.04$ & $-4.39 \pm 0.02$ & $-4.29 \pm 0.02$ & $-3.63 \pm 0.05$ & $-4.06 \pm 0.04$ \\
$\max$ & $-3.86 \pm 0.03$ & $-3.91 \pm 0.05$ & $-3.88 \pm 0.03$ & $-4.17 \pm 0.05$ & $-3.89 \pm 0.06$ & $-1.42 \pm 0.04$ & $-2.47 \pm 0.05$ \\
$\Delta^{26} \mathrm{Mg}$ & 0.32 & 0.44 & 0.14 & 0.22 & 0.40 & 2.21 & 1.59 \\
\hline
\end{tabular}

value whilst the most recent data point (dated at $0.7 \mathrm{ka} \mathrm{BP}$ ) has a lower $\mathrm{Mg}$ isotope composition.

The results from the fluid inclusion test runs are presented in Table 4 and Fig. 4 . The $\Delta^{26} \mathrm{Mg}$ between bulk (with intact fluid inclusions) and powdered samples (without fluid inclusions) does not exceed the second decimal. Nevertheless, powdered samples are systematically lower by 0.01 to $0.08 \%$ in their $\mathrm{Mg}$-isotope composition relative to their aliquots containing fluid inclusions (Fig. 4). The trend in $\mathrm{Mg}$-isotopes with time is the same for the powdered samples and the bulk samples (Fig. 4). From this it is concluded that the $\delta^{26} \mathrm{Mg}$ values of the fluid contained in these inclusions shift the bulk calcite $\mathrm{Mg}$-isotope composition towards higher values. This is because the fluid representing the drip water chemistry - enriched in ${ }^{26} \mathrm{Mg}$ relative to the calcite (Galy et al., 2002; Young and Galy, 2004; Immenhauser et al., 2010; Riechelmann et al., 2012b) - is influenced by the same factors as the calcite that precipitated from this fluid (Riechelmann et al., 2012b). Error bars of all these samples, however, exceed the $\Delta^{26} \mathrm{Mg}$, and therefore the potential impact of fluid inclusions on calcite $\delta^{26} \mathrm{Mg}$ is not considered of significance here.

\subsection{Stalagmite BU 4, Bunker Cave, Germany}

Holocene to recent $(2007 \mathrm{AD})$ stalagmite $\mathrm{BU} 4 \delta^{26} \mathrm{Mg}$ values range from $-4.34 \pm 0.07 \%$ o to $-3.91 \pm 0.05 \%$ o with a mean value of $-4.20 \pm 0.10 \%$ (Figs. 2 and 5a, Tables 2 and 3). Between 8.2 and $7.8 \mathrm{ka} \mathrm{BP}$, a trend towards lower values is found that reverses at around 7.6 ka BP. Lower $\delta^{26} \mathrm{Mg}$ values are again observed between 7.0 and $6.0 \mathrm{ka}$ BP. The highest $\delta^{26} \mathrm{Mg}$ value coincides with a hiatus marked by coralloid layer and detrital material dated 5.5 ka BP. Subsequent speleothem calcite precipitated between 3.9 to $1.8 \mathrm{ka}$ BP with decreasing $\delta^{26} \mathrm{Mg}$ values. Between 1.8 and $1.1 \mathrm{ka} \mathrm{BP}, \delta^{26} \mathrm{Mg}$ values are invariant with one higher value at $1.1 \mathrm{ka} B P$. The lowest measured value occurred at $0.4 \mathrm{ka}$ BP. Subsequently, $\delta^{26} \mathrm{Mg}$ values are slightly higher.

\subsection{Stalagmites NC-A and NC-B, Cueva del Tigre Perdido, Peru}

Upper Pleistocene to recent stalagmites NC-A and NCB $\delta^{26} \mathrm{Mg}$ values range from $-4.03 \pm 0.04 \%$ to $-3.88 \pm$
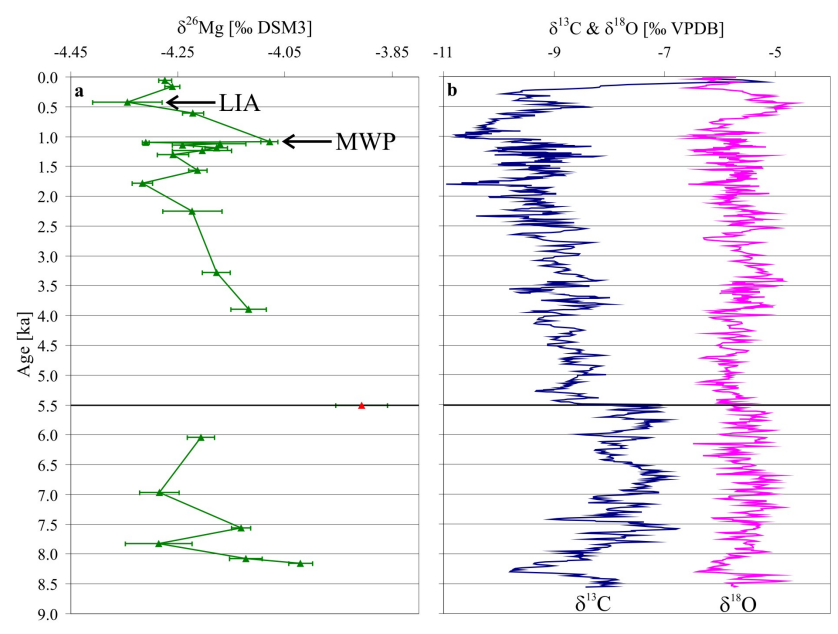

Fig. 5. Magnesium, carbon and oxygen isotope data of the stalagmite BU 4 from Bunker Cave, Germany. Black line marks hiatus characterized by a coralloid layer and detrital material. (a) Mgisotope data plotted against age in ka BP. Red triangle indicates sample taken in a detritus layer. (b) Carbon (dark blue) and oxygen (magenta) isotope data plotted against age in ka BP (data from Fohlmeister et al., 2012). Samples taken at the time of the Medieval Warm Period (MWP) and of the Little Ice Age (LIA) are indicated with black arrows.

$0.03 \%$ with a mean of $-3.96 \pm 0.04 \%$ (Figs. 2 and 6a, Tables 2 and 3). Magnesium isotope values in speleothem NC-B (13.1 to $3.6 \mathrm{ka}$ ) are invariant with fluctuations mostly within the analytical error. Speleothem NC-A data show slightly higher $\delta^{26} \mathrm{Mg}$ values at $2.8 \mathrm{ka} \mathrm{BP}$, and at $1.9 \mathrm{ka} \mathrm{BP}$ the $\delta^{26} \mathrm{Mg}$ value is lower. The last point at $0.06 \mathrm{ka} \mathrm{BP}$ is again higher. These shifts, however, barely exceed the error bars of NC-B.

\subsection{Stalagmite GDA, Grotte d'Aoufous, Morocco}

Pleistocene (dated using one U-Pb age of $2.134 \pm 0.115 \mathrm{Ma}$, Table 1) stalagmite GDA $\delta^{26} \mathrm{Mg}$ values range from $-4.39 \pm 0.02 \%$ o to $-4.17 \pm 0.05 \%$ with a mean value of $-4.26 \pm 0.07 \%$ (Figs. 2 and 7a, Tables 2 and 3). Age dating was performed by the U-Pb method (measured at the University of Berne, Switzerland); therefore, error bars are large. From the base of the stalagmite GDA, $\delta^{26} \mathrm{Mg}$ values show 
Table 4. Magnesium isotope composition of several samples of the stalagmite AH-1 measured with and without fluid inclusions and the calculated $\Delta^{26} \mathrm{Mg}$ between these samples.

\begin{tabular}{lrrrrrr}
\hline $\begin{array}{l}\text { Speleo- } \\
\text { them }\end{array}$ & Sample & $\begin{array}{r}\delta^{26} \mathrm{Mg} \\
\text { [\%o DSM3] } \\
\text { total sample }\end{array}$ & $\pm 2 \sigma$ & $\begin{array}{r}\delta^{26} \mathrm{Mg} \\
\text { [\%o DSM3] } \\
\text { without fluids }\end{array}$ & $\pm 2 \sigma$ & $\Delta^{26} \mathrm{Mg}$ \\
\hline AH-1 & 05 & -4.08 & 0.06 & -4.10 & 0.02 & 0.03 \\
AH-1 & 2 & -3.95 & 0.03 & -3.97 & 0.05 & 0.02 \\
AH-1 & 4 & -3.99 & 0.05 & -4.00 & 0.05 & 0.01 \\
AH-1 & 6 & -3.97 & 0.04 & -4.03 & 0.01 & 0.06 \\
AH-1 & 17 & -3.93 & 0.03 & -4.00 & 0.06 & 0.08 \\
AH-1 & 23 & -3.98 & 0.05 & -4.03 & 0.02 & 0.05 \\
AH-1 & 24 & -3.97 & 0.05 & -3.98 & 0.05 & 0.02 \\
AH-1 & 26 & -3.98 & 0.05 & -4.01 & 0.04 & 0.03 \\
AH-1 & 27 & -3.94 & 0.07 & -3.98 & 0.02 & 0.03 \\
\hline
\end{tabular}
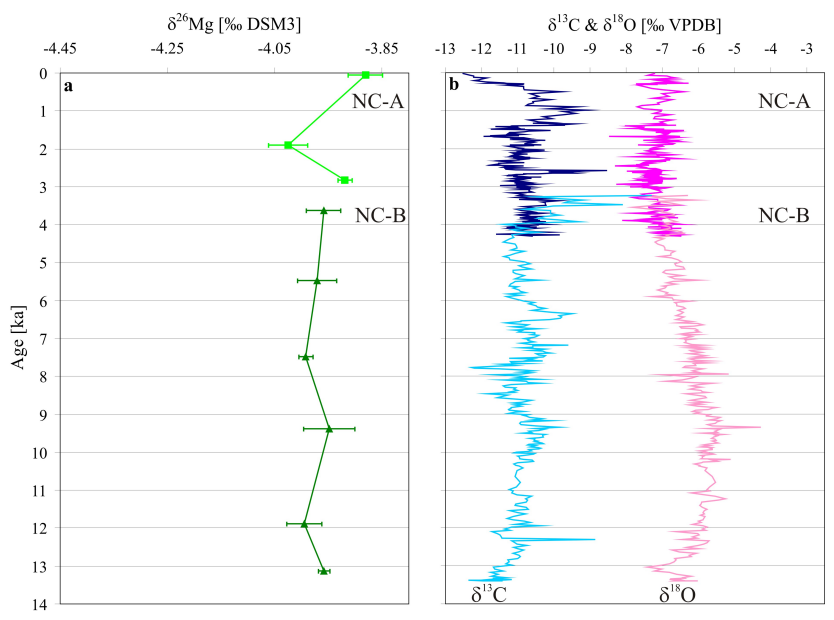

Fig. 6. Magnesium, carbon and oxygen isotope data of stalagmites NC-A and NC-B from Cueva del Tigre Perdido, Peru. (a) Mgisotope data (NC-A: light green squares; NC-B: green triangles) plotted against age in ka BP using the StalAge model of Scholz and Hoffmann (2011). (b) Carbon (NC-A: dark blue; NC-B: light blue) and oxygen (NC-A: magenta; NC-B: light magenta) isotope data plotted against age in ka BP (data from van Breukelen et al., 2008 and van Breukelen, 2009).

lower values in the lower third of the stalagmite, i.e. between 13.6 and $9.7 \mathrm{~cm}$ distance from the top (dft) of the stalagmite. At $8.9 \mathrm{~cm}$ dft, i.e. the middle part, a higher $\delta^{26} \mathrm{Mg}$ value is recorded reaching plateau values between 8.9 and $7.7 \mathrm{~cm}$ dft. The magnesium isotope composition is again higher at $6.3 \mathrm{dft}$, and a second plateau phase is reached between 6.3 and $3.1 \mathrm{~cm} \mathrm{dft}$, whilst $\delta^{26} \mathrm{Mg}$ is again lower at $2.3 \mathrm{~cm} \mathrm{dft}$.

\subsection{Stalagmite HK3, Grotte Prison de Chien, Morocco}

The Pleistocene to Holocene stalagmite HK3 consists of several primary aragonitic and calcitic layers reflecting alternating more arid (aragonite) and less arid (calcite) climate
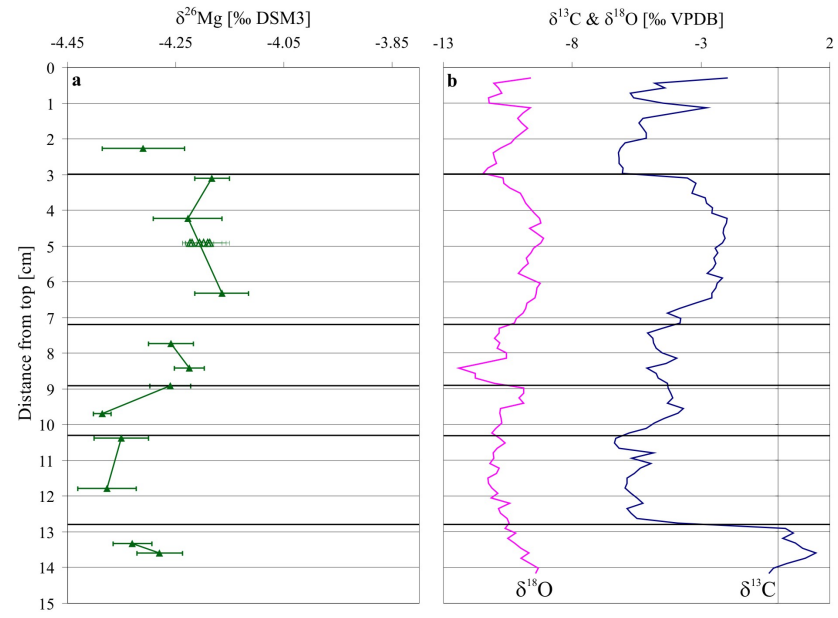

Fig. 7. Magnesium, carbon and oxygen isotope data of the stalagmite GDA from Grotte d'Aoufous, Morocco. Black lines mark hiatuses. (a) $\mathrm{Mg}$-isotope data are plotted against distance from top in $\mathrm{cm}$. Open triangles indicate multiple samples along a single growth layer (Buhl et al., 2007). (b) Carbon (dark blue) and oxygen (magenta) isotope data plotted against distance from top in $\mathrm{cm}$ (data from Buhl et al., 2007).

conditions. Data from samples across two transitions from aragonite to calcite and from calcite to aragonite are used and were described in detail in Wassenburg et al. (2012). The transitions are located between two age points: 27.48 and $23.53 \mathrm{ka} \mathrm{BP}$ (Wassenburg et al., 2012). Samples from the low-Mg aragonite layers were not analysed as the Mg content of aragonite is too low. The calcite layer yields $\delta^{26} \mathrm{Mg}$ values between $-4.29 \pm 0.02 \%$ and $-3.89 \pm 0.06 \%$ (mean: $-4.17 \pm 0.05 \%$; Figs. 2 and 8a, Tables 2 and 3). Overall, $\delta^{26} \mathrm{Mg}$ of the calcite increases towards the overlying aragonite intervals, whilst isotope ratios remain invariant in the central portions of the calcite interval (Fig. 8a). 

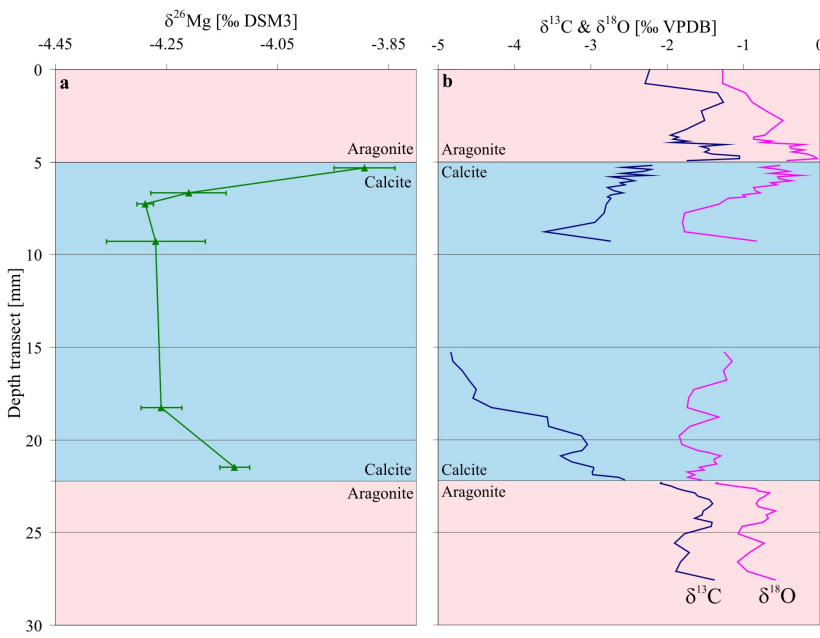

Fig. 8. Magnesium, carbon and oxygen data of the stalagmite HK3 from Grotte Prison de Chien, Morocco. (a) Mg-isotope data plotted against depth of the transect (top at $0 \mathrm{~mm}$ ). (b) Carbon (dark blue) and oxygen (magenta) isotope data plotted against depth (data from Wassenburg et al., 2012). Colour code refers to aragonite and calcite intervals, respectively.

\subsection{Flowstones SPA 52 and SPA 59, Spannagel Cave, Austria}

The Pleistocene flowstones SPA 52 and SPA $59 \delta^{26} \mathrm{Mg}$ values show ranges from $-3.63 \pm 0.05 \%$ o to $-1.42 \pm 0.04 \%$ o (mean: $-3.00 \pm 0.73 \%$ ) and from $-4.06 \pm 0.04 \%$ o to $-2.47 \pm 0.05 \%$ (mean: $-3.70 \pm 0.43 \%$; Figs. $2,9 \mathrm{a}$ and $10 \mathrm{a}$, Tables 2 and 3), respectively. The highest $\delta^{26} \mathrm{Mg}$ value for SPA 52 is located at $0.7 \mathrm{~cm}$ distance from base $(\mathrm{dfb})$ in a detrital layer followed by a lower value at $7.0 \mathrm{~cm} \mathrm{dfb}$ (Fig. 9a). Between 7.0 and $9.1 \mathrm{~cm} \mathrm{dfb}$, the values slightly increase again. At $10.3 \mathrm{~cm}$ dfb the $\delta^{26} \mathrm{Mg}$ value is slightly lower. The sample at $13.2 \mathrm{~cm} \mathrm{dfb}$ is higher in its $\mathrm{Mg}$ isotope composition and is located in a calcite layer containing small amounts of detritus. After a hiatus of ca. $53 \mathrm{ka}$, the $\delta^{26} \mathrm{Mg}$ values are again higher (at $14.4 \mathrm{~cm} \mathrm{dfb}$ ) and are again lower at $16.7 \mathrm{~cm}$ dfb (Fig. 9a). These two sample points coincide with detrital layers.

Between 25.4 to $33.6 \mathrm{~mm}$ distance from base (dfb), the $\delta^{26} \mathrm{Mg}$ values of SPA 59 are low before the $\delta^{26} \mathrm{Mg}$ value is higher at $41.1 \mathrm{~mm} \mathrm{dfb} \mathrm{(Fig.} \mathrm{10a).} \mathrm{This} \mathrm{sample} \mathrm{was} \mathrm{taken} \mathrm{at}$ a hiatus with detrital material at the top. At $56.4 \mathrm{~mm}$ dfb the $\delta^{26} \mathrm{Mg}$ value is lower before the highest value is reached at $60.3 \mathrm{~mm}$ dfb $\left(\delta^{26} \mathrm{Mg}:-2.47 \%\right.$; Fig. 10a). Samples taken at 47.5 and $60.3 \mathrm{~mm} \mathrm{dfb}$ contain detrital material. Afterwards, the $\delta^{26} \mathrm{Mg}$ values are again lower $65.7 \mathrm{~mm}$ dfb and show a decreasing trend to $80.5 \mathrm{~mm} \mathrm{dfb}$. A slight increase occurs between 80.5 and $94.2 \mathrm{~mm}$ dfb followed by a decrease to $110.9 \mathrm{~mm}$ dfb (Fig. 10a).

Sample SPA 52 f $\left(\delta^{26} \mathrm{Mg}:-1.42 \pm 0.04 \%\right.$; Table 2) and sample SPA $59 \mathrm{~b}\left(\delta^{26} \mathrm{Mg}:-2.47 \pm 0.05 \%\right.$; Table 2$)$

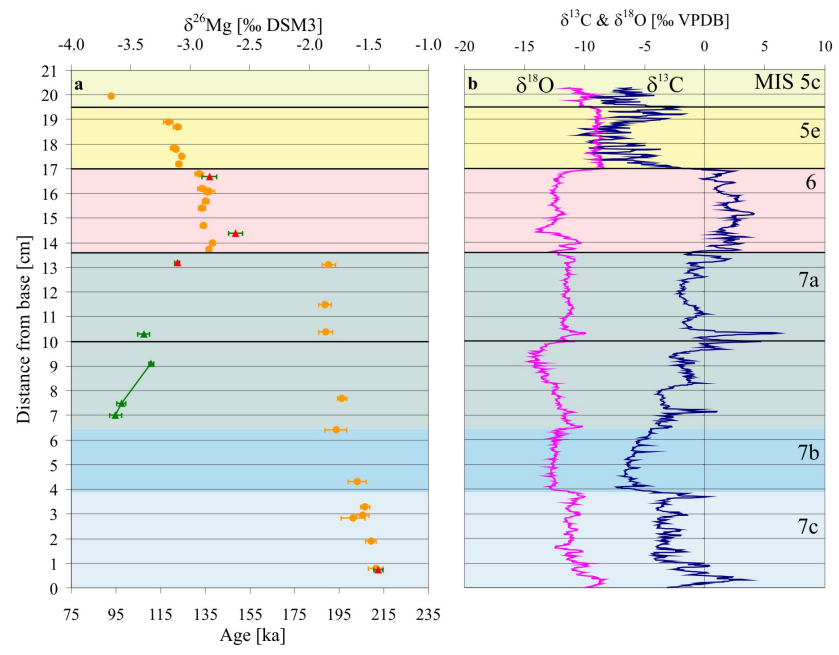

Fig. 9. Magnesium, carbon and oxygen isotope data and age data of flowstone SPA 52 from Spannagel Cave, Austria. Thick black lines indicate hiatuses. (a) Mg-isotope data (green) and age data (orange) plotted against distance from base in $\mathrm{cm}$ (age data from Spötl et al., 2007). Red triangles indicate samples taken in detritus layers. (b) Carbon (dark blue) and oxygen (magenta) isotope data plotted against distance from base in $\mathrm{cm}$ (data from Spötl et al., 2007). Marine isotope stages (MIS) after Spötl et al. (2007).

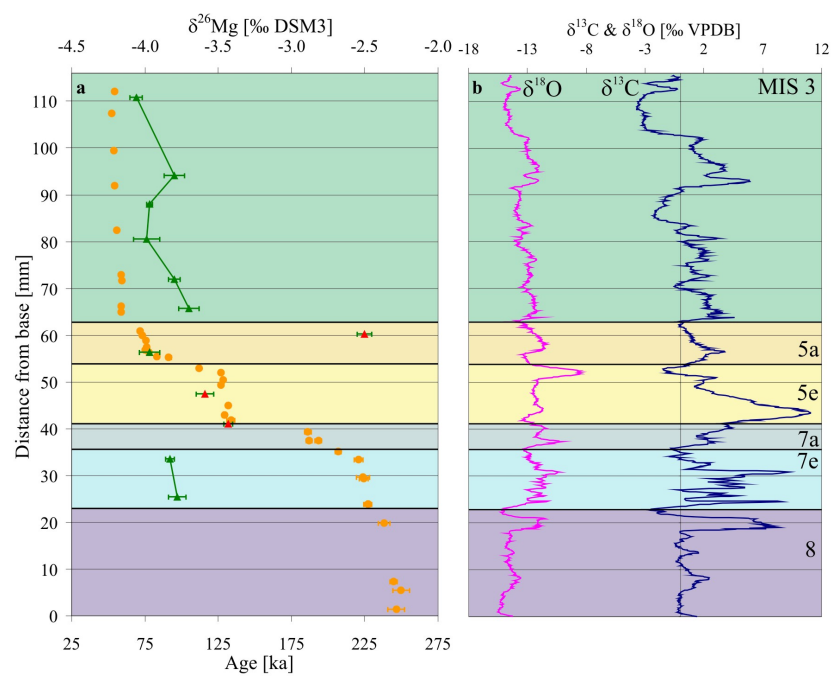

Fig. 10. Magnesium, carbon and oxygen isotope data and age data of flowstone SPA 59 from Spannagel Cave, Austria. Thick black lines indicate hiatuses. (a) Mg-isotope data (green) and age data (orange) plotted against distance from base in $\mathrm{mm}$ (age data from Holzkämper et al., 2005). Red triangles indicate samples taken in detritus layers. (b) Carbon (dark blue) and oxygen (magenta) isotope data plotted against distance from base in $\mathrm{mm}$ (data from Holzkämper et al., 2005). Marine isotope stages after Spötl et al. (2007). 
are taken from thick detrital layers with a high clay mineral content and are therefore highly ${ }^{26} \mathrm{Mg}$-enriched compared to samples from detritus-free calcite layers. Given that these data points are not representing the calcite $\delta^{26} \mathrm{Mg}$ values, mean values should be calculated without samples containing detritus (the corrected mean $\delta^{26} \mathrm{Mg}$ SPA 52 is thus $-3.48 \pm 0.15 \%$; the corrected mean $\delta^{26} \mathrm{Mg}$ SPA 59 is $-3.88 \pm 0.12 \%$ ) .

\section{Interpretation and discussion}

The study sites are grouped into the following present-day climate regions: (i) warm temperate and semi-arid (dry and hot summers) to arid (desert and hot arid) climate in Morocco; (ii) warm temperate (warm summers) and humid climate in western Germany; (iii) equatorial-humid climate in Peru and (iv) alpine climate (humid, snow-rich winters and cold summers) in Austria (Kottek et al., 2006). Given that most of the following factors directly relate to climate, the discussion of $\mathrm{Mg}$-isotope data is organized according to climate zones.

\subsection{Warm-(semi-)arid climate: speleothem time series $\delta^{26} \mathrm{Mg}$ data from Morocco}

Factors affecting weathering rates in carbonate-silicate settings are complex, spatially diverse and debated in the literature (Tipper et al., 2006a; Li et al., 2010; Pokrovsky et al., 2011). Nevertheless, rainwater abundance and residence time in the soil as well as biogenic soil activity are considered significant (Tipper et al., 2006a, 2010; Li et al., 2010). Related to these factors, changes in the soil clay mineral to host limestone weathering balance affect the soil and aquifer water $\delta^{26} \mathrm{Mg}$ values. Following the above discussion, a relative increase in the weathering of soil clay minerals induces higher $\delta^{26} \mathrm{Mg}$ values. Under most hydrogeochemical conditions, the limestone and dolostone solubility in soil water and aquifer waters exceeds that of clay minerals (Appelo and Postma, 2005). Nevertheless, even a slightly increased solubility of Mg-bearing clay minerals will be recorded in soilzone and karst aquifer waters due to their high Mg-content and higher $\delta^{26} \mathrm{Mg}$ values (Riechelmann et al., 2012b). Where dolostones or dolomite-rich limestones form the cave host rock, the impact of silicate-derived ${ }^{26} \mathrm{Mg}$ on water isotope ratios will be subdued (Galy et al., 2002) due to the Mg-rich host rock mineralogy.

The Moroccan stalagmite HK3, characterized by alternating aragonitic and calcitic intervals, documents the above relationships (Fig. 8). Due to the low abundance of $\mathrm{Mg}$ in aragonite (Okrusch and Matthes, 2005), sampling was restricted to the calcite intervals. Based on high-resolution carbon and oxygen isotope data as well as elemental abundances, Wassenburg et al. (2012) documented that, during more arid periods, aragonite precipitation was favoured whilst calcite layers typify less arid conditions. During more arid phases, two main factors trigger aragonite precipitation. These include (i) the increased residence time of water in the soil as well as in the karst system, where clays with a high $\mathrm{Mg}$ isotope composition are leached, and (ii) prior calcite precipitation, which takes place in the karst aquifer zone (i.e. the precipitation of calcite prior to reaching the stalagmite surface), leading to a higher $\mathrm{Mg} / \mathrm{Ca}$ ratio of the fluid. The fact that the host rock contains dolomite (Table 1) results in an enriched $\mathrm{Mg}$-content of the drip water, too. In addition, prior calcite precipitation also increases the $\mathrm{pH}$ of the fluid and lowers the fluid saturation state. These factors give rise to aragonite precipitation (Frisia and Borsato, 2010; Wassenburg et al., 2012).

We used the stalagmite HK3 Mg-isotope ratios to test the above-described impact of increasing aridity and soil water residence time on the Mg-isotope signature. In essence, rainfall amount predictably decreases towards the calciteto-aragonite transition (27.48 to $23.53 \mathrm{ka} \mathrm{BP}$ ), whilst soil water residence time and silicate weathering rates in the aquifer should increase. Under increased input of isotopically higher, clay-derived $\mathrm{Mg}$, a shift towards higher values near the calcite-to-aragonite transition is expected. Indeed, this shift in isotope ratios in the calcite layer near the transition to aragonite $\left(\Delta^{26} \mathrm{Mg}=0.36 \%\right.$ ) is observed (Fig. 8a). Carbon, oxygen and magnesium isotopes show a highly similar trend in the calcite layer (Fig. 8). Hence, Mg-isotope data support the interpretation that aragonite precipitated under more arid conditions (enhanced silicate weathering) and calcite precipitated under less arid conditions (reduced silicate weathering). However, near the calcite-to-aragonite transition the presence of very small amounts of aragonite within the calcite is possible. Since the fractionation of carbon and oxygen isotopes is different for aragonite and calcite (Romanek et al., 1992; Kim and O'Neil, 1997), it may be possible that different fractionation factors also apply for $\mathrm{Mg}$. Therefore, changes in the Mg-isotope composition near the calcite-to-aragonite transition might also be induced by a change of the fractionation factor. However, neither microscopical work nor carbon and oxygen isotopic compositions provide an indication of aragonite in the calcite samples.

The Mg-isotope record of the calcitic stalagmite GDA from Grotte d'Aoufous is equally well understood in the context of aridity changes. The Mg-isotope data (Fig. 7a) were thought to reflect changes between more or less arid conditions, which were in accordance with $\delta^{18} \mathrm{O}, \delta^{13} \mathrm{C}, \mathrm{Sr}$ and $\mathrm{Mg}$ elemental data and $\mathrm{Sr}$ isotopes (Buhl et al., 2007). Similar to the Moroccan stalagmite HK3, the $\delta^{26} \mathrm{Mg}$ values of the GDA show a similar pattern as the $\delta^{13} \mathrm{C}$ and $\delta^{18} \mathrm{O}$ values (Fig. 7). Problems arise because stalagmite GDA is considerably older (U-Pb age of $2.134 \pm 0.115 \mathrm{Ma}$ ) and speleothem growth in the Grotte d'Aoufous ceased several times in the Pleistocene (Buhl et al., 2007). Climate reconstructions from Larrasoaña et al. (2003) and Feddi et al. (2011), however, support the interpretation of stalagmite GDA from Buhl et 
al. (2007). For the Gelasian (1.806-2.588 Ma), i.e. the time interval that coincides with the U-Pb age of stalagmite GDA, Larrasoaña et al. (2003) found changes in the dust amount, interpreted as changes in the amount of rainfall that coincides with changes of the 400-kyr component of the eccentricity. According to these authors, changes between more arid and less arid conditions occur during the Gelasian. Similarly, Feddi et al. (2011) documented evidence for temperature shifts in the Gelasian as based on pollen analyses. These general patterns are arguably recorded in stalagmite GDA, which is therefore showing changes between more arid and warm and less arid and warm conditions in its Mg-isotope composition.

The host rock $\delta^{26} \mathrm{Mg}$ value of Grotte d'Aoufous $(-3.63 \pm 0.08 \%$; Fig. 2; Buhl et al., 2007), a Turonian marine limestone, is slightly higher than that of the Devonian host rock ( $-3.72 \pm 0.07 \%$; Fig. 2; Immenhauser et al., 2010) of the caves in Germany discussed below. Aquifer water residence times under the arid conditions that characterize the northern rim of the Sahara were expectedly longer than those in the warm-humid climate in Germany. Hence, lower $\delta^{26} \mathrm{Mg}$ values for the Moroccan stalagmite GDA could be expected.

In essence, the concepts as explained above provide a comparably robust and internally consistent interpretation for the $\delta^{26} \mathrm{Mg}$ record of the two Moroccan speleothems shown here. Combined with evidence from $\mathrm{Sr}$ and $\mathrm{Mg}$ abundances and calcite ${ }^{87} \mathrm{Sr} /{ }^{86} \mathrm{Sr}$ ratios - i.e. more radiogenic ${ }^{87} \mathrm{Sr} /{ }^{86} \mathrm{Sr}$ under more arid conditions due to longer silicate rock/water interaction (Buhl et al., 2007) - it is proposed that shifts towards lower $\delta^{26} \mathrm{Mg}, \delta^{13} \mathrm{C}$ and $\delta^{18} \mathrm{O}$ values (Figs. 7 and 8 ) represent less arid and perhaps lower temperatures whilst higher isotope ratios point to more arid and hot desert climate (Fig. 12). The above considerations suggest that speleothem $\mathrm{Mg}$ isotope data from warm-(semi-)arid settings are useful and sensitive proxies for climate-driven changes in the carbonatesilicate weathering balance.

\subsection{Equatorial-humid climate: speleothem time series $\delta^{26} \mathrm{Mg}$ data from Peru}

The Holocene climate in Peru differs significantly from that of the Moroccan case examples. The present-day rainfall amount in the vicinity of the Cueva del Tigre Perdido is around $1344 \mathrm{~mm} \mathrm{yr}^{-1}$ (Table 1; Sträßer, 1999); and was probably on the order of $940-1140 \mathrm{~mm} \mathrm{yr}^{-1}$ at the beginning of the Holocene (15-30\% increase of rainfall amount during the Holocene; van Breukelen et al., 2008), a value that indicates an overall very humid climate. Average annual temperatures seem to have remained rather constant through the Holocene (van Breukelen et al., 2008). This overall pattern is documented in the $\delta^{18} \mathrm{O}$ data of the calcite that decrease during the Holocene due to a gradual increase of rainfall amount (van Breukelen et al., 2008). It seems likely that water residence times were short due to the constantly high rainfall

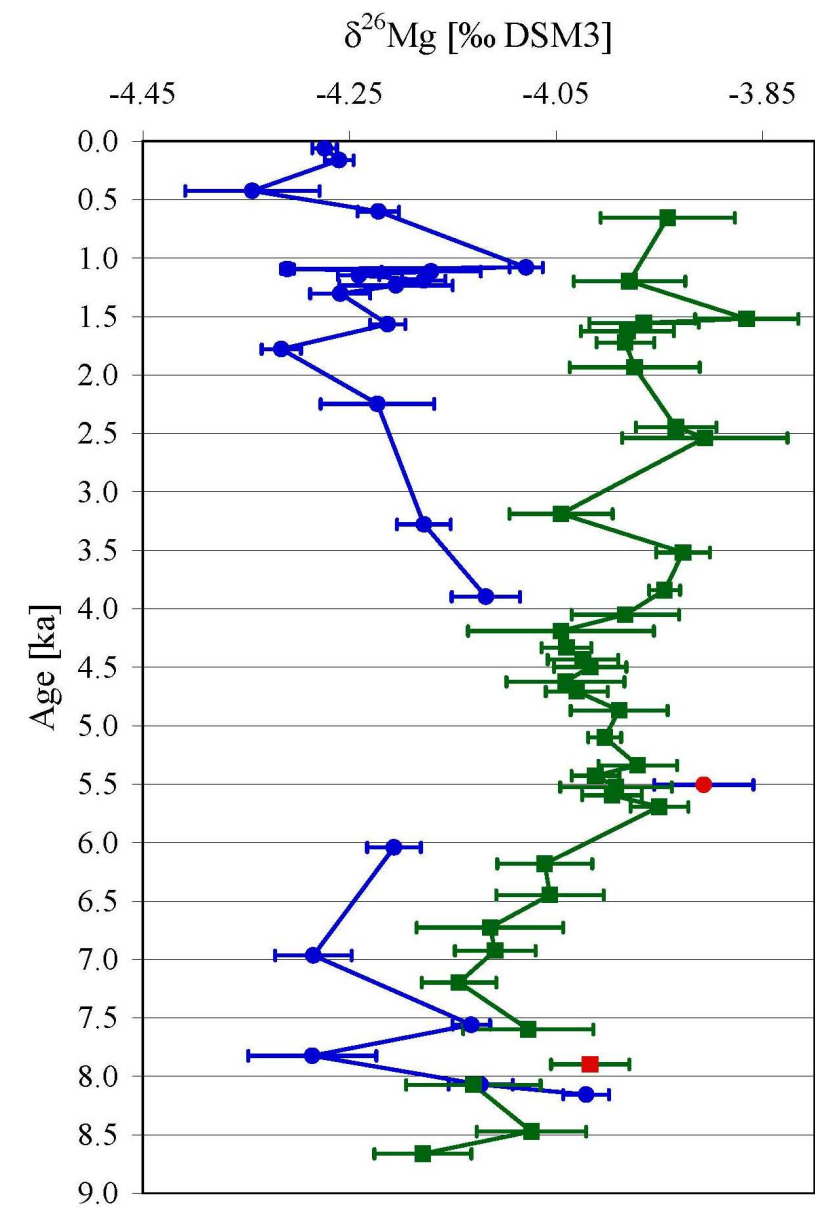

Fig. 11. Magnesium isotope records of the stalagmites AH-1 (green squares) and BU 4 (blue circles) from Germany plotted against age in ka BP. Samples taken from detrital layers are marked with red squares or circles.

amount at this site. Therefore, no changes in the Mg-isotope ratios should be expected.

In contrast to the Moroccan case examples, the Peruvian stalagmites NC-A and NC-B lack a correlation between $\delta^{26} \mathrm{Mg}$ and $\delta^{13} \mathrm{C}$ and $\delta^{18} \mathrm{O}$ values, respectively (Fig. 6). Applying the concepts laid out above, the limited changes in the (short) soil water residence and a rather constant carbonate versus silicate weathering ratio throughout the Late Pleistocene to Late Holocene - the soil is mainly composed of kaolinite and Mg-bearing montmorillonite (Sanchez and Buol, 1974) - resulted in invariant $\delta^{26} \mathrm{Mg}$ values in stalagmite NC-B (Fig. 6a). In contrast, the Late Holocene to recent NC-A speleothem recorded subtle changes in the $\delta^{26} \mathrm{Mg}$ values barely exceeding the analytical error that are not reflected in the $\mathrm{C}$ or $\mathrm{O}$ isotope ratios. Considering the limitations of the low temporal resolution of $\mathrm{Mg}$ isotope sampling points and the invariant $\mathrm{Mg}$-isotope signatures, it is here proposed that the Peruvian stalagmites represent an endmember case setting that is less suitable for $\mathrm{Mg}$ isotope proxy data. 


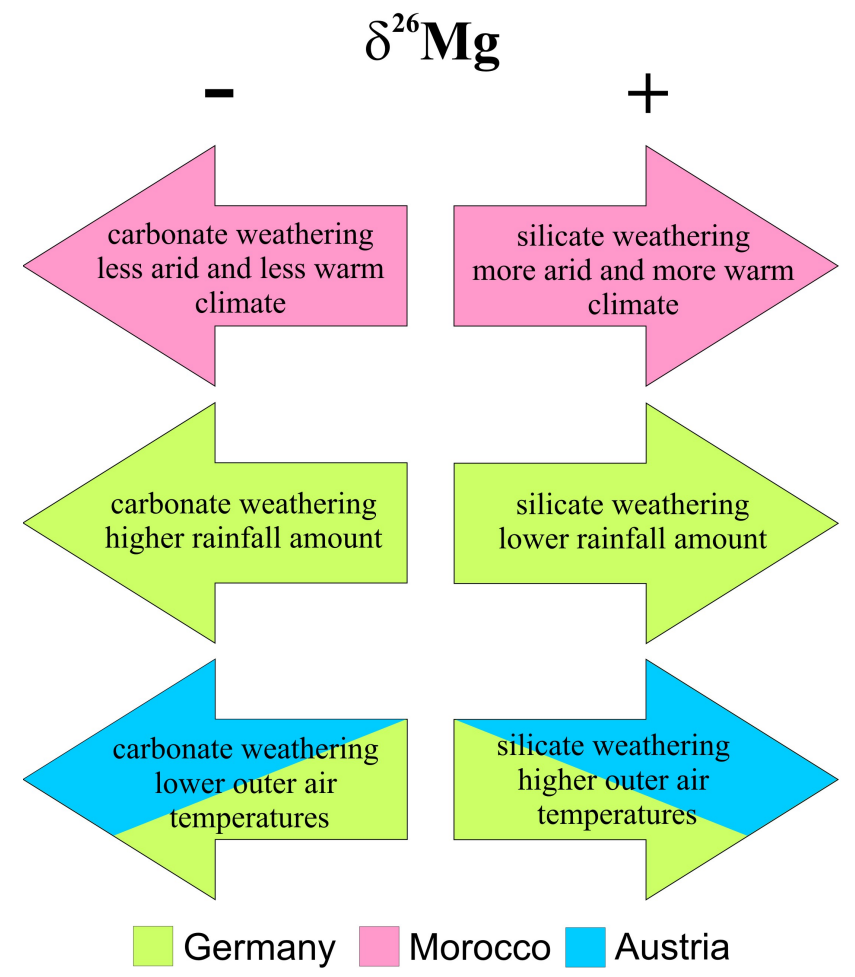

Fig. 12. Conceptual model summarising factors affecting $\mathrm{Mg}$ isotope ratios of speleothems from four different climate zones.

\subsection{Warm-humid climate: speleothem time series $\delta^{26} \mathrm{Mg}$ data from Germany}

The interpretation of speleothem $\delta^{26} \mathrm{Mg}$ time series data from Atta and Bunker Caves is challenging. Given the very comparable climate setting, host rock composition $\left(\delta^{26} \mathrm{Mg}\right.$ : $-3.72 \pm 0.07 \%$; Fig. 2; Immenhauser et al., 2010) and soil properties, we suggest that the same set of factors drives $\mathrm{Mg}$ fractionation in these two caves. Differences between the two sites include drip characteristics as well as drip water chemistry.

Both drip sites show only slight differences in their drip rate (AH-1: $0.019 \pm 0.001 \mathrm{ml} \mathrm{min}^{-1}$ (Niggemann, 2000); BU 4: $0.002 \pm 0.001 \mathrm{ml} \mathrm{min}^{-1}$ ) but the same drip characteristic (seepage flow) using the terminology of Baker et al. (1997) and Smart and Friederich (1987). The fact that the drip rate of the AH-1 drip site is ten times faster than that of the BU 4 drip site probably suggests that the water feeding the AH-1 drip site (Atta Cave) has a shorter water residence time compared to that of the BU 4 drip site (Bunker Cave). This assumption is supported by field evidence given that speleothem $\mathrm{BU} 4$ is characterized by a lower mean $\delta^{26} \mathrm{Mg}$ value $(-4.20 \pm 0.10 \%$; Figs. 2 and 11 and Table 3$)$ compared to speleothem AH-1 $(-4.01 \pm 0.07 \%$ o, Figs. 2 and 11 and Table 3). This because the aquifer water in Bunker Cave has a longer reaction time with the isotopically ${ }^{26} \mathrm{Mg}$-depleted host rock in the karst zone.
Nevertheless, differences in drip water chemistry might also be the reason for the differences in mean $\mathrm{Mg}$-isotope composition of $0.19 \%$ between these two caves. Drip water samples taken above $\mathrm{AH}-1$ are considerably enriched in $\mathrm{Mg}$ $(\mathrm{Mg} / \mathrm{Ca}$ ratio: 0.67; Niggemann, 2000$)$ relative to drip water samples taken above $\mathrm{BU} 4(\mathrm{Mg} / \mathrm{Ca}$ ratio: 0.06$)$. Higher $\mathrm{Mg}$ concentrations in the aquifer may be due to dolomitisation of the limestone along fissures in the host rock (Krebs, 1978). Water feeding the drip site of AH-1 is possibly percolating along these dolomitised fissures. This seems not to be the case for the drip water of BU 4. Given that dolomite is generally elevated in $\delta^{26} \mathrm{Mg}$ relative to limestone ( $\mathrm{Li}$ et al., 2012), higher mean $\delta^{26} \mathrm{Mg}$ values of $\mathrm{AH}-1$ drip water are expected and found.

The portion of stalagmite $\mathrm{AH}-1$ representing the time interval between 9.0 to $6.0 \mathrm{ka} \mathrm{BP}$ is characterized by a dark and compact crystal fabric. Calcite precipitated between $6 \mathrm{ka}$ $\mathrm{BP}$ and present is typified by a white and porous crystal fabric. Lower $\delta^{26} \mathrm{Mg}$ values correspond to the dark and compact crystal fabric, and higher $\delta^{26} \mathrm{Mg}$ values correspond to the white and porous crystal fabric.

In AH-1, carbon and oxygen isotope values (Fig. 3b) are higher in the dark, compact fabric (9.0 to $6.0 \mathrm{ka} \mathrm{BP})$, a fact that was interpreted as evidence for overall drier climate conditions (Niggemann et al., 2003). As argued in Riechelmann et al. (2012b), drier climate in essence shifts the silicate versus carbonate weathering ratio towards isotopically higher (silicate) values. Higher $\delta^{26} \mathrm{Mg}$ values would be expected rather than lower values as observed. Between 6.0 and the present day, the climate was overall wetter (Niggemann et al., 2003 ) and higher $\delta^{26} \mathrm{Mg}$ values are found as opposed to lower $\delta^{26} \mathrm{Mg}$ values as expected for dominant carbonate weathering under wetter conditions. Based on the $\delta^{18} \mathrm{O}$ record of stalagmite AH-1, Mangini et al. (2007) proposed an overall climatic warming for the last $6 \mathrm{ka} \mathrm{BP}$.

The following lines of evidence (Riechelmann et al., $2012 \mathrm{~b}$ ) suggest that, under an overall humid climate and increasing mean air temperature, microbial soil-zone activity is favoured (Harper et al., 2005). Related to this, the weathering of Mg-bearing clay minerals such as montmorillonite, chlorite and illite in the soil zone is increased. The general shift in $\delta^{26} \mathrm{Mg}_{\mathrm{AH}-1}$ towards higher values may bear witness of an overall increased influx of clay-derived ${ }^{26} \mathrm{Mg}$. If these considerations are true, the general trend in $\mathrm{AH}-1 \delta^{26} \mathrm{Mg}$ values is mainly outside air temperature controlled. Between 9 to $6 \mathrm{ka} \mathrm{BP}$, carbonate weathering increased relative to clay mineral weathering in the soil zone due to colder temperatures. Between $6 \mathrm{ka}$ BP to present, a renewed increase in outside air temperature favoured silicate weathering in the soil zone (Figs. 3a and 12).

Using oxygen isotope data of AH-1 (Niggemann, 2000; Niggemann et al., 2003) as a tentative benchmark against which the smaller variations in $\delta^{26} \mathrm{Mg}$ values are calibrated, the following pattern emerges: Shifts towards higher $\delta^{26} \mathrm{Mg}$ values took place when mean rainfall amounts decreased, 
whilst shifts towards lower $\delta^{26} \mathrm{Mg}$ values coincided with overall more humid climate (Figs. 3 and 12).

The stalagmite BU 4 consists of a columnar fabric with the exception of a thin interval dated as $7.6 \mathrm{ka} \mathrm{BP}$ that is characterized by dendritic crystals (Riechelmann, 2010). It is of interest to note that $\delta^{26} \mathrm{Mg}$ shifts to higher values at this level (Fig. 5a), but the relation between crystallography and $\mathrm{Mg}$ isotope ratios is still underexplored. Columnar crystal fabrics are formed under stable precipitation conditions, while dendritic fabric forms preferentially under conditions far from equilibrium (Frisia et al., 2000; Frisia and Borsato, 2010).

Following Fohlmeister et al. (2012), $\delta^{18} \mathrm{O}$ data of BU 4 recorded changes in both temperature and rainfall amount at higher values the climate was cooler and drier and vice versa (Fig. 5b). The first-order signal of $\delta^{13} \mathrm{C}$ is influenced by vegetation cover above the cave while the second-order signal is influenced by drip rate (Fohlmeister et al., 2012). Between 9 to $7 \mathrm{ka}$ BP soil respiration was lower leading to higher $\delta^{13} \mathrm{C}$ values. After $7 \mathrm{ka} \mathrm{BP}$ the $\delta^{13} \mathrm{C}$ values decrease, which is due to a denser vegetation cover and thus higher soil respiration (Fohlmeister et al., 2012). Periods of lower drip rate lead to higher $\delta^{13} \mathrm{C}$ values and vice versa (Fohlmeister et al., 2012).

Between 8.2 and $6.0 \mathrm{ka} \mathrm{BP}$, the $\delta^{13} \mathrm{C}$ and $\delta^{18} \mathrm{O}$ values of BU 4 indicate a trend to drier and cooler climate with less soil respiration (Fig. 5b), whilst the Mg-isotope composition decreases (Fig. 5a). Following our previous set of arguments, this points to a shift towards carbonate weathering with temperature overruling rainfall amount as the driving factor (Fig. 12).

From 5.5 to $1.8 \mathrm{ka} \mathrm{BP}, \delta^{13} \mathrm{C}$ and $\delta^{26} \mathrm{Mg}$ values both show a decreasing trend (Fig. 5). Soil respiration expectedly increased during this time due to the development of a denser vegetation cover (Fohlmeister et al., 2012). Hence, the production of $\mathrm{CO}_{2}$ is increased and leads to higher dissolution rates of the low-Mg calcite host rock due to the increased amount of carbonic acid in the karst system. Also, the decalcification of the loess (at present a loess loam) may have led to decreasing $\delta^{26} \mathrm{Mg}$ values. Therefore, decreasing $\delta^{26} \mathrm{Mg}$ values may be due to enhanced dissolution of carbonate between 5.5 to $1.8 \mathrm{ka}$ BP. The processes might also apply between 5.7 and $4.2 \mathrm{ka}$ BP for speleothem AH1 (Fig. 11). Here, a decreasing trend in the $\delta^{26} \mathrm{Mg}$ values is noted (Figs. 3a and 11), whilst $\delta^{13} \mathrm{C}$ values decrease but to a lesser degree (Fig. 3b). However, enhanced soil respiration leads also to an increase in silicate weathering, which would result in higher $\delta^{26} \mathrm{Mg}$ values. Nevertheless, it can be assumed that $\mathrm{Mg}$ derived from carbonate occurs in a much higher amount than that derived from silicate during the development of the vegetation. The direct comparison of the Bunker Cave stalagmites $\delta^{18} \mathrm{O}$ record with that of the Atta Cave stalagmite AH-1 reveals similar patterns (Fohlmeister et al., 2012). This observation is considered evidence that stalagmites in both caves recorded essentially the same environmental signals.
BU 4 magnesium-isotope ratios between 1.6 and $0.7 \mathrm{ka} \mathrm{BP}$ anti-correlate with BU $4 \delta^{13} \mathrm{C}$ and $\delta^{18} \mathrm{O}$ values (Fig. 5). As a consequence, it seems that temperature is again the factor dominating soil processes and, linked to this, weathering ratios (Fig. 12). Between 1.1 to $0.7 \mathrm{ka}$, the Medieval Warm Period (Fohlmeister et al., 2012) is characterized by lower $\delta^{13} \mathrm{C}$ and $\delta^{18} \mathrm{O}$ and higher $\delta^{26} \mathrm{Mg}$ values (Fig. 5), perhaps explained by an overall wetter (Niggemann, 2000; Trouet et al., 2009; Büntgen et al., 2011; Fohlmeister et al., 2012) and warmer climate for this region (Goosse et al., 2006; Mann et al., 2009; Trouet et al., 2009; Büntgen et al., 2011; Fohlmeister et al., 2012).

The Little Ice Age, dated between 0.7 to $0.2 \mathrm{ka}$, is characterized by a shift to higher values in $\delta^{13} \mathrm{C}$ and $\delta^{18} \mathrm{O}$ and lower $\delta^{26} \mathrm{Mg}$ values (Fig. 5; Fohlmeister et al., 2012) indicating overall drier and cooler climate conditions. This is consistent with the results of previous studies also reporting drier (Niggemann, 2000; Fohlmeister et al., 2012) and cooler conditions for the Little Ice Age for this region (Jones and Mann, 2004; Luterbacher et al., 2004; Xoplaki et al., 2005; Goosse et al., 2006; Mann et al., 2009). With respect to the Little Ice Age and Medieval Warm Period, several reconstructions of air temperatures, applying a diverse set of proxies, and modelling approaches have been published (Mann and Jones, 2003; Jones and Mann, 2004; Luterbacher et al., 2004; Xoplaki et al., 2005; Goosse et al., 2006; Mann et al., 2009; Trouet et al., 2009; Büntgen et al., 2011). Depending on the proxy used, these studies suggest air temperature variability on the order of a few degrees celsius over the last millennium. A critical assessment of these data, however, reveals that different temperature proxies react differently in terms of their sensitivity for temperature variations (Mann and Jones, 2003; Luterbacher et al., 2004). Also, hydrological variability (Mann and Jones, 2003) and non-climatic signals (Goosse et al., 2006) affect different proxies in a different manner. Moreover, statements regarding past temperature variations should be made only when acknowledging significant uncertainties (Mann and Jones, 2003; Luterbacher et al., 2004; Xoplaki et al., 2005; Goosse et al., 2006; Mann et al., 2009; Trouet et al., 2009; Büntgen et al., 2011). Finally, regional and global temperature trends differ in most cases. This is as regional variations in air temperature tend to display considerably larger variations than coeval global fluctuations (Jones and Mann, 2004; Luterbacher et al. 2004). This becomes particularly obvious when considering longer time periods

However, given the low dependency of $\mathrm{Mg}$ isotope fractionation on temperature during calcite precipitation $\left(0.02 \%\right.$ o/AMU $/{ }^{\circ} \mathrm{C}$; Galy et al., 2002$)$, and the comparably small temperature changes over the last millennium, changes in mean cave air temperature on the order of $10^{\circ} \mathrm{C}$ would be required to explain the observed shifts in $\delta^{26} \mathrm{Mg}$. Evidence for a temperature shift on this order of magnitude is lacking, and temperature is thus ruled out as a main factor driving $\mathrm{Mg}$ isotope fractionation during calcite precipitation. 
In essence, the two cave records from Germany exemplify the full complexity of speleothem $\delta^{26} \mathrm{Mg}$ records in a setting characterized by comparably subtle climate changes over time. Based on the arguments brought forward here, it is suggested that weathering patterns in the soil zone above the caves as well as in the karst zone, driven by mean outside air temperature and rainfall amount, are the main driving factors in the $\delta^{26} \mathrm{Mg}$ records obtained (Fig. 12). In principle, all of these factors are present at all times but temperature seems to overrule rainfall amount in general.

\subsection{Cold-humid climate: speleothem time series $\delta^{26} \mathrm{Mg}$ data from Austria}

Speleothem deposition in the high-elevation Spannagel Cave is biased towards warm interglacial conditions. Cold-climate precipitation, however, has also been observed and attributed to the presence of sulphides in the host rock (providing acidity for karstification) and a warm-based ice cover (Spötl et al., 2007; Spötl and Mangini, 2007). In the present-day setting, sparse alpine meadows cover a soil above the cave and soil thickness does not exceed $20 \mathrm{~cm}$. Portions of the host rock above the cave lack soil and vegetation.

Carbon isotope ratios of both studied flowstones (Figs. 9b and 10b) are influenced by the composition of the marine marble host rock $\left(\delta^{13} \mathrm{C}\right.$ of +2 to $+3 \%$; Holzkämper et al., 2005 ) and the input of soil-derived organic $C$ in the drip water. Oxygen isotope values are high during warm and low during cold climate conditions. Low $\delta^{13} \mathrm{C}$ values imply more biological activity in the soil zone and vice versa (Spötl et al., 2007; Holzkämper et al., 2005). Decreasing $\delta^{13} \mathrm{C}$ values thus reflect a genuine vegetation signal during periods, when carbon is anti-correlated with oxygen, (Spötl et al., 2007; Holzkämper et al., 2005).

Both flowstones show similar patterns in $\delta^{26} \mathrm{Mg}$ and $\delta^{18} \mathrm{O}$ (Figs. 9 and 10). Higher values during warm conditions may thus imply more silicate weathering and vice versa. During interglacials the availability of water (rain, snow and ice melt) is higher than during glacial periods (Spötl et al., 2007). Speleothem deposition requires the presence of water in the aquifer, i.e. temperatures above the freezing point. Hence, changes in rainfall amount that in turn affect soil activity can be excluded as main factor controlling Mg-isotope fractionation in this specific setting. Having ruled out water availability as a controlling factor, temperature remains the main parameter controlling subtle changes in silicate versus carbonate weathering ratios (Fig. 12). This probably applies also for the Holocene with warm summer months and cold winter months ( 7 to 8 months of snow cover per year; Spötl et al., 2002).

Flowstone SPA 52 is characterized by considerably elevated mean $\delta^{26} \mathrm{Mg}$ values of $-3.48 \pm 0.15 \%$ o relative to flowstone SPA $59\left(\delta^{26} \mathrm{Mg}:-3.88 \pm 0.12 \%\right.$ ) . This may indicate that the drip water feeding SPA 59 experienced an overall longer residence time. Furthermore, the marble host rock $\delta^{26} \mathrm{Mg}$ value is $-3.37 \pm 0.06 \%$ (Fig. 2) and therefore closer to the mean isotopic composition of SPA 52 relative to SPA 59 , a feature that is in good agreement with a short water residence time. However, the marble is situated between a paragneiss lithology (i.e. metamorphosed sedimentary rocks) beneath and an orthogneiss lithology (i.e. metamorphosed crystalline rocks) above. The $\delta^{26} \mathrm{Mg}$ value of the paragneiss is $-2.95 \pm 0.06 \%$ o (Fig. 2), which was not completely digested using our method (see Sect. 3). It can be assumed that the orthogneiss may have a similar Mg isotope composition. It is possible that the $\mathrm{Mg}$ isotope composition of the orthogneiss might shift the isotopic composition of the flowstones towards higher values; the input of $\mathrm{Mg}$ from the orthogneiss is, however, unknown and further work is required.

In conclusion, the Spannagel flowstones represent a cold, alpine endmember setting characterized by mainly temperature-driven weathering changes in the patchy and thin soil cover (Fig. 12). Warmer periods favour higher soilzone activity and increased silicate weathering leading to higher $\delta^{26} \mathrm{Mg}$ values.

\subsection{Potential, problems and future work}

Data shown here suggest that a limited, albeit complicated, bundle of parameters controls the $\mathrm{Mg}$ isotope composition of speleothems. Here, we show data from a series of climatic zones. Obviously, caves situated in climate domains characterized by pronounced changes in mean air temperature or rainwater availability are expectedly characterized by more pronounced shifts (Fig. 12). A prominent example is found in the data set from Morocco. Conversely, speleothem records characterized by rather constant climate parameters such as the Peruvian data show no statistically significant variability in $\delta^{26} \mathrm{Mg}$.

The interpretation of the $\delta^{26} \mathrm{Mg}$ records from caves in Germany is complex. This is because several of the factors, namely temperature and rainfall amount, control speleothem $\delta^{26} \mathrm{Mg}$ in a manner that differs from the Moroccan stalagmites $\delta^{26} \mathrm{Mg}$. In the cold, alpine endmember, outside air temperature seems to be the dominant driver of carbonatesilicate weathering patterns driving the $\delta^{26} \mathrm{Mg}$ variations.

One of the obvious strengths of the $\mathrm{Mg}$ isotope proxy is its sensitivity for subtle processes in the soil zone (weathering ratios; Buhl et al., 2007) and differences in soil and reservoir water residence time (Riechelmann et al., 2012b). Combined with elemental evidence and other isotope systems such as $\mathrm{Sr}, \mathrm{C}$, and $\mathrm{O}$, an improved understanding of soil zone processes can be achieved. Nevertheless, despite significant advances in the application of Mg-isotopes as a continental climate proxy, unsolved issues remain. Due to the low Mg content of many speleothems, the sample size required for $\delta^{26} \mathrm{Mg}$ analysis is large and - combined with the time-consuming and expensive analytical work inhibits high-resolution speleothem $\mathrm{Mg}$ isotope records similar to those commonly compiled for carbon or oxygen. 
Specifically, aragonite speleothems have low Mg amounts so that an interpretation of their $\delta^{26} \mathrm{Mg}$ records seems not feasible at present. The sampling of speleothem calcite containing detrital material should be avoided due to contamination problems. Colloidal particles (NOM - natural organic matter) are present in many speleothems in varying concentrations (Hartland et al., 2012). It is possible that $\mathrm{Mg}$ is bound to these particles in a similar manner as other trace elements. The work of Hartland et al. $(2011,2012)$ indicates that climate has an influence on the NOM-transported metals in speleothems and that the partitioning of metals between drip waters and speleothems may be restricted by binding with colloidal or dissolved NOM. In addition, the strength of binding, size and speciation of NOM-metal complexes may affect the partitioning of aqueous complexes into the calcite crystal lattice. However, it is unknown if these colloidal particles will be digested using the analytical method used here, and hence it is unclear whether colloid-bound $\mathrm{Mg}$ will be digested.

The dependency of the $\delta^{26} \mathrm{Mg}$ values on the calcite precipitation rate is known from laboratory precipitation experiments (Immenhauser et al., 2010), but awaits further work using water compositions and precipitation rates that are more similar to those found in nature, since there was no influence on $\delta^{26} \mathrm{Mg}$ values in natural samples observed.

Finally, an improved understanding of the factors that control Mg leaching from soil zone clay minerals and clay contained in host rock carbonates is required. Carefully established leaching experiments under controlled laboratory conditions might represent the way forward.

\section{Conclusions}

The analysis of $\mathrm{Mg}$ as well as $\mathrm{C}$ and $\mathrm{O}$ isotope ratios from eight speleothems representing five climate zones leads to the following conclusions:

1. The sensitivity of speleothem $\delta^{26} \mathrm{Mg}$ values to environmental and disequilibrium factors strongly depends on the overall climate setting. Pronounced variations in mean air temperature and rainfall amount with time, such as the case in the Pleistocene of Morocco, result in changes in the silicate versus carbonate weathering ratio that in turn affects drip water $\delta^{26} \mathrm{Mg}$ values in a predictable manner. Caves situated in invariant climate zones, such as tropical Peru during the Pleistocene to Holocene, are characterized by invariant $\delta^{26} \mathrm{Mg}$ records.

2. Stalagmite $\delta^{26} \mathrm{Mg}$ values from warm-temperate climate zones such as western Germany are more difficult to interpret. This is because here a set of driving factors interacts in a more complex manner. These factors include mean air temperature outside the cave and rainfall amount. These factors drive soil-zone activity and affect the subtle balance between silicate and carbonate weathering rates. Here, multi-proxy $\delta^{13} \mathrm{C}$ and $\delta^{18} \mathrm{O}$ data must be used in combination with $\delta^{26} \mathrm{Mg}$ data in order to obtain a coherent interpretation and to separate the relative effects of mean air temperature and rainfall amount on soil zone activity.

3. Layers of detrital material in speleothems must be avoided due to contamination problems. Particularly, Mg-bearing clay minerals shift bulk values to higher $\delta^{26} \mathrm{Mg}$ values.

4. In high-latitude and alpine climate settings exposed to pronounced changes in glacial and interglacial air temperature, the main driving factor of soil-zone activity and weathering ratios outside of the cave, and hence speleothem $\delta^{26} \mathrm{Mg}$ values, is air temperature.

5. Comparing host rock and mean $\delta^{26} \mathrm{Mg}$ stalagmite signatures, semi-quantitative estimates of aquifer water residence time can be obtained. Lower mean stalagmite $\delta^{26} \mathrm{Mg}$ values are found where host rock values are low and long residence time resulted in equilibration of $\delta^{26} \mathrm{Mg}_{\text {fluid }}$ with $\delta^{26} \mathrm{Mg}_{\text {hostrock }}$.

6. The results shown here summarise the present level of knowledge in speleothem $\mathrm{Mg}$ isotope proxy research. An improved understanding of the complex processes involved requires well-calibrated experimental work including leaching and precipitation experiments.

Acknowledgements. We thank our colleagues in the non-traditional isotope laboratory at Bochum for technical assistance. The Speleogroup Letmathe is thanked for supporting sample recovery in Atta and Bunker Cave. Uranium-lead age dating of the Grotte d'Aoufous stalagmite in Morocco was performed at the University of Berne, Switzerland. This is a contribution to the collaborative research initiative DAPHNE II, founded by the DFG. We greatly acknowledge the work of associated editor G. Lohmann and the very constructive comments by the reviewers J. Baldini and E. T. Tipper.

Edited by: G. Lohmann

\section{References}

Appelo, C. A. J. and Postma, D.: Geochemistry, groundwater and pollution, 2nd Edn., A.A. Balkema Publishers, Amsterdam, 649 pp., 2005.

Asrat, A., Baker, A., Leng, M. J., Gunn, J., and Umer, M.: Environmental monitoring in the Mechara caves, southeastern Ethiopia: Implications for speleothem palaeoclimate studies, Int. J. Speleol., 37, 207-220, 2008.

Baker, A. and Genty, D.: Environmental pressures on conserving cave speleothems: Effects of changing surface land use and increased cave tourism, J. Environ. Manage., 53, 165-175, 1998. 
Baker, A., Barnes, W. L., and Smart, P. L.: Variations in the discharge and organic matter content of stalagmite drip waters in Lower Cave, Bristol, Hydrol. Process., 11, 1541-1555, 1997.

Baldini, J. U. L., McDermott, F., Hoffmann, D. L., Richards, D. A., and Clipson, N.: Very high-frequency and seasonal cave atmosphere $\mathrm{P}_{\mathrm{co} 2}$ variability: Implications for stalagmite growth and oxygen isotope-based paleoclimate records, Earth Planet. Sci. Lett., 272, 118-129, doi:10.1016/j.epsl.2008.04.031, 2008.

Brenot, A., Cloquet, C., Vigier, N., Carignan, J., and France-Lanord, C.: Magnesium isotope systematics of the lithologically varied Moselle river basin, France, Geochim. Cosmochim. Ac., 72, 5070-5089, doi:10.1016/j.gca.2008.07.027, 2008.

Buhl, D., Immenhauser, A., Smeulders, G., Kabiri, L., and Richter, D. K.: Time series $\delta^{26} \mathrm{Mg}$ analysis in speleothem calcite: Kinetic versus equilibrium fractionation, comparison with other proxies and implications for palaeoclimate research, Chem. Geol., 244, 715-729, doi:10.1016/j.chemgeo.2007.07.019, 2007.

Büntgen, U., Tegel, W., Nicolussi, K., McCormick, M., Frank, D., Trouet, V., Kaplan, J. O., Herzig, F., Heussner, K.-U., Wanner, H., Luterbacher, J., and Esper, J.: 2500 years of European climate variability and human susceptibility, Science, 331, 578582, doi:10.1126/science.1197175, 2011.

Cruz Jr., F. W., Burns, S. J., Jercinovic, M., Karmann, I., Sharp, W. D., and Vuille, M.: Evidence of rainfall variations in Southern Brazil from trace element ratios $(\mathrm{Mg} / \mathrm{Ca}$ and $\mathrm{Sr} / \mathrm{Ca})$ in a Late Pleistoene stalagmite, Geochim. Cosmochim. Ac., 71, 22502263, doi:10.1016/j.gca.2007.02.005, 2007.

Daëron, M., Guo, W., Eiler, J., Genty, D., Blamart, D., Boch, R., Drysdale, R., Maire, R., Wainer, K., and Zanchetta, G.: ${ }^{13} \mathrm{C}^{18} \mathrm{O}$ clumping in speleothems: Observations from natural caves and precipitation experiments, Geochim. Cosmochim. Ac., 75, 33033317, doi:10.1016/j.gca.2010.10.032, 2011.

Day, C. C. and Henderson, G. M.: Oxygen isotopes in calcite grown under cave-analogue conditions, Geochim. Cosmochim. Ac., 75, 3956-3972, doi:10.1016/j.gca.2011.04.026, 2011.

DePaolo, D. J.: Surface kinetic model for isotopic and trace element fractionation during precipitation of calcite from aqueous solutions, Geochim. Cosmochim. Ac., 75, 1039-1056, doi:10.1016/j.gca.2010.11.020, 2011.

de Villiers, S., Dickson, J. A. D., and Ellam, R. M.: The composition of the continental river weathering flux deduced from seawater $\mathrm{Mg}$ isotopes, Chem. Geol., 216, 133-142, doi:10.1016/j.chemgeo.2004.11.010, 2005.

Dorale, J. A., Edwards, R. L., Ito, E., and González, L. A.: Climate and vegetation history of the midcontinent from 75 to $25 \mathrm{ka}$ : a speleothem record from Crevice Cave, Missouri, USA, Science, 282, 1871-1874, 1998.

Dreybrodt, W. and Scholz, D.: Climatic dependence of stable carbon and oxygen isotope signals recorded in speleothems: From soil water to speleothem calcite, Geochim. Cosmochim. Ac., 75, 734-752, doi:10.1016/j.gca.2010.11.002, 2011.

Egli, M., Mirabella, A., and Sartori, G.: The role of climate and vegetation in weathering and clay mineral formation in later Quaternary soils of the Swiss and Italian Alps, Geomorphology, 102, 307-324, doi:10.1016/j.geomorph.2008.04.001, 2008.

Fairchild, I. J. and McMillan, E. A.: Speleothems as indicators of wet and dry periods, Int. J. Speleo., 36, 69-74, 2007.

Feddi, N., Fauquette, S., and Suc, J.-P.: Histoire plio-pléistocène des écosytèmes végétaux de méditerranée sud-occidentale: Ap- port de l'analyse pollinique de deux sondages en mer d'alboran, GEOBIOS, 44, 57-69, doi:10.1016/j.geobios.2010.03.007, 2011.

Fohlmeister, J., Schröder-Ritzrau, A., Scholz, D., Spötl, C., Riechelmann, D. F. C., Mudelsee, M., Wackerbarth, A., Gerdes, A., Riechelmann, S., Immenhauser, A., Richter, D. K., and Mangini, A.: Bunker Cave stalagmites: an archive for central European Holocene climate variability, Clim. Past Discuss., 8, 1687-1720, doi:10.5194/cpd-8-1687-2012, 2012.

Frisia, S. and Borsato, A.: Karst, in: Carbonates in continental settings: Facies, environments and processes, edited by: AlonsoZarza, A. M. and Tanner, L. H., Developments in Sedimentology, 61, Elsevier, Amsterdam, 269-318, 2010.

Frisia, S., Borsato, A., Fairchild, I. J., and McDermott, F.: Calcite fabrics, growth mechanisms, and environments of formation in speleothems from the Italian Alps and southwestern Ireland, J. Sediment. Res., 70, 1183-1196, 2000.

Frisia, S., Borsato, A., Fairchild, I. J., McDermott, F., and Selmo, E. M.: Aragonite-calcite relationships in speleothems (Grotte de Clamouse, France): Environment, fabrics, and carbonate geochemistry, J. Sediment. Res., 72, 687-699, 2002.

Galy, A., Bar-Matthews, M., Halicz, L., and O’Nions, R. K.: Mg isotopic composition of carbonate: Insight from speleothem formation., Earth Planet. Sci. Lett., 201, 105-115, 2002.

Genty, D. and Massault, M.: Carbon transfer dynamics from bomb- ${ }^{14} \mathrm{C}$ and $\delta^{13} \mathrm{C}$ time series of a laminated stalagmite from SW France - modelling and comparison with other stalagmite records, Geochim. Cosmochim. Ac, 63, 1537-1548, 1999.

Goosse, H., Arzel, O., Luterbacher, J., Mann, M. E., Renssen, H., Riedwyl, N., Timmermann, A., Xoplaki, E., and Wanner, H.: The origin of the European "Medieval Warm Period", Clim. Past, 2, 99-113, doi:10.5194/cp-2-99-2006, 2006.

Harper, C. W., Blair, J. M., Fay, P. A., Knapp, A. K., and Carlisle, J. D.: Increased rainfall variability and reduced rainfall amount decreases soil $\mathrm{CO}_{2}$ flux in a grassland ecosystem, Global Change Biol., 11, 322-334, doi:10.1111/j.13652486.2005.00899.x, 2005.

Hartland, A., Fairchild, I. J., Lead, J. R., Zhang, H., and Baalousha, M.: Size, speciation and lability of NOM-metal complexes in hyperalkaline cave dripwater, Geochim. Cosmochim. Ac., 75, 7533-7551, doi:10.1016/j.gca.2011.09.030, 2011.

Hartland, A., Fairchild, I. J., Lead, J. R., Borsato, A., Baker, A., Frisia, S., and Baalousha, M.: From soil to cave: Transport of trace metals by natural organic matter in karst dripwaters, Chem. Geol., 304-305, 68-82, doi:10.1016/j.chemgeo.2012.01.032, 2012.

Holzkämper, S., Spötl, C., and Mangini, A.: High-precision constraints on timing of alpine warm periods during the middle to late Pleistocene using speleothem growth periods, Earth Planet. Sci. Lett., 236, 751-764, doi:10.1016/j.eps1.2005.06.002, 2005.

Huang, Y. and Fairchild, I. J.: Partitioning of $\mathrm{Sr}^{2+}$ and $\mathrm{Mg}^{2+}$ into calcite under karst-analogue experimental conditions, Geochim. Cosmochim. Ac., 65, 47-62, 2001.

Immenhauser, A., Buhl, D., Richter, D. K., Niedermayr, A., Riechelmann, D., Dietzel, M., and Schulte, U.: Magnesiumisotope fractionation during low- $\mathrm{Mg}$ calcite precipitation in a limestone cave - field study and experiments, Geochim. Cosmochim. Ac., 74, 4346-4364, doi:10.1016/j.gca.2010.05.006, 2010. 
Jones, P. D. and Mann, M. E.: Climate over past millennia, Rev. Geophys., 42, RG2002, doi:10.1029/2003RG000143, 2004.

Kim, S.-T. and O'Neil, J. R.: Equilibrium and non-equilibrium oxygen isotope effects in synthetic carbonates, Geochim. Cosmochim. Ac., 61, 3461-3475, 1997.

Kluge, T., Marx, T., Scholz, D., Niggemann, S., Mangini, A., and Aeschbach-Hertig, W.: A new tool for palaeoclimate reconstruction: Noble gas temperatures from fluid inclusions in speleothems, Earth Planet. Sci. Lett., 269, 408-415, doi:10.1016/j.epsl.2008.02.030, 2008.

Kluge, T., Affek, H. P., Marx, T., Aeschbach-Hertig, W., Riechelmann, D. F. C., Scholz, D., Riechelmann, S., Immenhauser, A., Richter, D. K., Fohlmeister, J., Wackerbarth, A., Mangini, A., and Spötl, C.: Reconstruction of drip-water $\delta^{18} \mathrm{O}$ based on calcite oxygen and clumped isotopes of speleothems from Bunker Cave (Germany), Clim. Past Discuss., 8, 2853-2892, doi:10.5194/cpd8-2853-2012, 2012.

Komadel, P. and Madejová, J.: Acid activation of clay minerals, in: Handbook of clay science, edited by: Bergaya, F., Theng, B. K. G., and Lagaly, G., Developments in clay science, 1, Elsevier Ltd., Amsterdam, 263-287, 2006.

Kottek, M., Grieser, J., Beck, C., Rudolf, B., and Rubel, F.: World map of the Köppen-Geiger climate classification updated, Meteorol. Z., 15, 259-263, doi:10.1127/0941-2948/2006/0130, 2006.

Krebs, W.: Massenkalk, in: Geologische Karte von NordrheinWestfalen 1:25.000, Erläuterungen zu Blatt 4813 Attendorn, 2nd Edn., edited by: Ziegler, W., Geologisches Landesamt Nordrhein-Westfalen, Krefeld, Germany, 78-94, 1978.

Lachniet, M. S., Asmerom, Y., Burns, S. J., Patterson, W. P., Polyak, V. J., and Seltzer, G. O.: Tropical response to the 8200 yr B.P. cold event? Speleothem isotopes indicate a weakened early Holocene monsoon in Costa Rica, Geology, 32, 957-960, doi:10.1130/G20797.1, 2004.

Larrasoaña, J. C., Roberts, A. P., Rohling, E. J., Winkelhofer, M., and Wehausen, R.: Three million years of monsoon variability over the northern Sahara, Clim. Dynam., 21, 689-698, doi:10.1007/s00382-003-0355-z, 2003.

Li, S.-L., Liu, C.-Q., Li, J., Lang, Y.-C., Ding, H., and Li, L.: Geochemistry of dissolved inorganic carbon and carbonate weathering in a small typical karstic catchment of southwest China: Isotopic and chemical constraints, Chem. Geol., 277, 301-309, doi:10.1016/j.chemgeo.2010.08.013, 2010.

Li, W., Chakraborty, S., Beard, B. L., Romanek, C. S., and Johnson, C. M.: Magnesium isotope fractionation during precipitation of inorganic calcite under laboratory conditions, Earth Planet. Sci. Lett., 333-334, 304-316, doi:10.1016/j.eps1.2012.04.010, 2012.

Luterbacher, J., Dietrich, D., Xoplaki, E., Grosjean, M., and Wanner, H.: European seasonal and annual temperature variability, trends and extremes since 1500, Science, 303, 1499-1503, doi:10.1126/science.1093877, 2004.

Madejová, J., Bujdák, J., Janek, M., and Komadel, P.: Comparative FT-IR study of structural modifications during acid treatment of dioctahedral smectites and hectorite, Spectrochim.Acta A, 54, 1397-1406, 1998.

Maher, K.: The dependence of chemical weathering rates on fluid residence time, Earth Planet. Sci. Lett., 294, 101-110, doi:10.1016/j.epsl.2010.03.010, 2010.

Mangini, A., Spötl, C., and Verdes, P.: Reconstruction of temperature in the central Alps during the past $2000 \mathrm{yr}$ from a $\delta^{18} \mathrm{O}$ stalagmite record, Earth Planet. Sci. Lett., 235, 741-751, doi:10.1016/j.eps1.2005.05.010, 2005.

Mangini, A., Verdes, P., Spötl, C., Scholz, D., Vollweiler, N., and Kromer, B.: Persistent influence of the North Atlantic hydrography on central European winter temperature during the last 9000 years, Geophys. Res. Lett., 34, L02704, doi:10.1029/2006GL028600, 2007.

Mann, M. E. and Jones, P. D.: Global surface temperatures over the past two millennia, Geophys. Res. Lett., 30, 1820-1823, doi:10.1029/2003GL017814, 2003.

Mann, M. E., Zhang, Z., Rutherford, S., Bradley, R. S., Hughes, M. K., Shindell, D., Ammann, C., Faluvegi, G., and Ni, F. Global signatures and dynamical origins of the Little Ice Age and Medieval Climate Anomaly, Science, 326, 1256-1260, doi:10.1126/science.1177303, 2009.

Miorandi, R., Borsato, A., Frisia, S., Fairchild, I. J., and Richter, D. K.: Epikarst hydrology and implications for stalagmite capture of climate changes at Grotta di Ernesto (N.E. Italy): Results from long-term monitoring, Hydrolog. Process., 24, 3101-3114, doi:10.1002/hyp.7744, 2010.

Mühlinghaus, C., Scholz, D., and Mangini, A.: Modelling stalagmite growth and $\delta^{13} \mathrm{C}$ as a function of drip interval and temperature, Geochim. Cosmochim. Ac., 71, 2780-2790, doi:10.1016/j.gca.2007.03.018, 2007.

Niggemann, S.: Klimabezogene Untersuchungen an spät- bis postglazialen Stalagmiten aus Massenkalkhöhlen des Sauerlandes, in: Beiträge zur Speläologie I., edited by: Richter, D. K. and Wurth, G., Bochumer Geol. u. Geotechn. Arb., Bochum, 5-129, 2000.

Niggemann, S., Mangini, A., Mudelsee, M., Richter, D. K., and Wurth, G.: Sub-Milankovitch climatic cycles in Holocene stalagmites from Sauerland, Germany, Earth Planet. Sci. Lett., 216, 539-547, doi:10.1016/S0012-821X(03)00513-2, 2003.

Okrusch, M. and Matthes, S.: Mineralogie - Eine Einführung in die spezielle Mineralogie, Petrologie und Lagestättenkunde, 7th Edn., Springer, Berlin Heidelberg New York, 526 pp., 2005.

Pokrovsky, B. G., Mavromatis, V., and Pokrovsky, O. S.: Covariation of $\mathrm{Mg}$ and $\mathrm{C}$ isotopes in late Precambrian carbonates of the Siberian platform: A new tool for tracing the change in weathering regime?, Chem. Geol., 290, 67-74, doi:10.1016/j.chemgeo.2011.08.015, 2011.

Polag, D., Scholz, D., Mühlinghaus, C., Spötl, C., Schröder-Ritzrau, A., Segl, M., and Mangini, A.: Stable isotope fractionation in speleothems: Laboratory experiments, Chem. Geol., 279, 31-39, doi:10.1016/j.chemgeo.2010.09.016, 2010.

Reynard, L. M., Day, C. C., and Henderson, G. M.: Large fractionation of calcium isotopes during cave-analogue calcium carbonate growth, Geochim. Cosmochim. Ac., 75, 3726-3740, doi:10.1016/j.gca.2011.04.010, 2011.

Richter, D. K., Meissner, P., Immenhauser, A., Schulte, U., and Dorsten, I.: Cryogenic and non-cryogenic pool calcites indicating permafrost and non-permafrost periods: a case study from the Herbstlabyrinth-Advent Cave system (Germany), The Cryosphere, 4, 501-509, doi:10.5194/tc-4-501-2010, 2010.

Riechelmann, D. F. C.: Aktuospeläologische Untersuchungen in der Bunkerhöhle des Iserlohner Massenkalks (NRW/Deutschland): Signifikanz für kontinentale Klimaarchive, Ph.D. thesis, Fakultät für Geowissenschaften, Ruhr-Universität Bochum, Germany, Bochum, 199 pp., 2010. 
Riechelmann, D. F. C., Schröder-Ritzrau, A., Scholz, D., Fohlmeister, J., Spötl, C., Richter, D. K., and Mangini, A.: Monitoring Bunker Cave (NW Germany): A prerequisite to interpret geochemical proxy data of speleothems from this site, J. Hydrol., 409, 682-695, 2011.

Riechelmann, D. F. C., Deininger, M., Scholz, D., Riechelmann, S., Schröder-Ritzrau, A., Spötl, C., Richter, D. K., Immenhauser, A., and Mangini, A.: Disequilibrium carbon and oxygen isotope fractionation in recent cave calcite: Comparison of cave precipitate and numerical model $\delta^{13} \mathrm{C}$ and $\delta^{18} \mathrm{O}$ data, Geochim. Cosmochim. Ac., accepted, doi:10.1016/j.gca.2012.11.002, 2012a.

Riechelmann, S., Buhl, D., Schröder-Ritzrau, A., Spötl, C., Riechelmann, D. F. C., Richter, D. K., Kluge, T., Marx, T., and Immenhauser, A.: Hydrogeochemistry and fractionation pathways of $\mathrm{Mg}$ isotopes in a continental weathering system: Lessons from field experiments, Chem. Geol., 300-301, 109122, doi:10.1016/j.chemgeo.2012.01.025, 2012b.

Romanek, C. S., Grossman, E. L., and Morse, J. W.: Carbon isotopic formation in synthetic aragonite and calcite: Effects of temperature and precipitation rate, Geochim. Cosmochim. Ac., 56, 419430, 1992

Rudzka, D., McDermott, F., Baldini, L. M., Fleitmann, D., Moreno, A., and Stoll, H.: The coupled $\delta^{13} \mathrm{C}$-radiocarbon systematics of three late glacial/early Holocene speleothems; insights into soil and cave processes at climate transition, Geochim. Cosmochim. Ac., 75, 4321-4339, doi:10.1016/j.gca.2011.05.022, 2011.

Sanchez, P. A. and Buol, S. W.: Properties of some soils of the upper Amazon basin of Peru, Soil Sci. Soc. Am. Proc., 38, 117-121, 1974.

Scheidegger, Y., Kluge, T., Kipfer, R., Aeschbach-Hertig, W., and Wieler, R.: Paleotemperature reconstruction using noble gas concentrations in speleothem fluid inclusions, PAGES News, 16, 1012, 2008.

Scholz, D. and Hoffmann, D. L.: StalAge - an algorithm designed for construction of speleothem age models, Quat. Geochronol., 6, 369-382, doi:10.1016/j.quageo.2011.02.002, 2011.

Scholz, D., Mühlinghaus, C., and Mangini, A.: Modelling $\delta^{13} \mathrm{C}$ and $\delta^{18} \mathrm{O}$ in the solution layer on stalagmite surfaces, Geochim. Cosmochim. Ac., 73, 2592-2602, doi:10.1016/j.gca.2009.02.015, 2009.

Sherwin, C. M. and Baldini, J. U. L.: Cave air and hydrological controls on prior calcite precipitation and stalagmite growth rates: Implications for palaeoclimate reconstructions using speleothems, Geochim. Cosmochim. Ac., 75, 3915-3929, doi:10.1016/j.gca.2011.04.020, 2011.

Smart, P. L. and Friederich, H.: Water movement and storage in the unsaturated zone of a maturely karstified carbonate aquifer, Mendip Hills, England, Proceedings of the Environmental Problems in Karst Terranes and their Solutions Conference, Bowling Green, Kentucky, USA, 57-87, 1987.

Spötl, C. and Mangini, A.: Speleothems and paleoglaciers, Earth Planet. Sci. Lett., 254, 323-331, 2007.

Spötl, C., Mangini, A., Frank, N., Eichstädter, R., and Burns, S. J.: Start of the last interglacial period at $135 \mathrm{ka}$ : Evidence from a high alpine speleothem, Geology, 30, 815-818, 2002.

Spötl, C., Fairchild, I. J., and Tooth, A. F.: Cave air control on dripwater geochemistry, Obir Caves (Austria): Implications for speleothem deposition in dynamically ventilated caves, Geochim. Cosmochim. Ac., 69, 2451-2468, doi:10.1016/j.gca.2004.12.009, 2005.

Spötl, C., Holzkämper, S., and Mangini, A.: The last and the penultimate interglacial as recorded by speleothems from a climatically sensitive high-elevation cave site in the Alps, in: The climate of past interglacials, edited by: Sirocko, F., Claussen, M. Litt, T., and Sánchez-Goñi, M. F., Developments in quaternary science series, 7, Elsevier, Amsterdam, 471-491, 2007.

Sträßer, M.: Klimadiagramm-Atlas der Erde Teil 1: Europa und Nordamerika. Monats- und Jahresmittelwerte von Temperatur und Niederschlag für den Zeitraum 1961-1990, Duisburger geographische Arbeiten, 18, edited by: Blotevogel, H. H., Eckart, K., Flüchter, W., Habrich, W., Sträßer, M., and Wagner, E., Dortmunder Vertrieb für Bau- und Planungsliteratur, Dortmund, 222 pp., 1998.

Sträßer, M.: Klimadiagramm-Atlas der Erde Teil 2: Asien, Lateinamerika, Afrika, Australien und Ozeanien, Polarländer. Monats- und Jahresmittelwerte von Temperatur und Niederschlag für den Zeitraum 1961-1990, Duisburger Geographische Arbeiten, 20, edited by: Blotevogel, H. H., Eckart, K., Flüchter, W., Habrich, W., Sträßer, M., and Wagner, E., Dortmunder Vertrieb für Bau- und Planungsliteratur, Dortmund, 254 pp., 1999.

Tipper, E. T., Galy, A., and Bickle, M. J.: Riverine evidence for a fractionated reservoir of $\mathrm{Ca}$ and $\mathrm{Mg}$ on the continents: Implications for the oceanic Ca cycle, Earth Planet. Sci. Lett., 247, 267-279, 2006a.

Tipper, E. T., Galy, A., Gaillardet, J., Bickle, M. J., Elderfield, H., and Carder, E. A.: The magnesium isotope budget of the modern ocean: Constraints from riverine magnesium isotope ratios, Earth Planet. Sci. Lett., 250, 241-253, doi:10.1016/j.eps1.2006.07.037, $2006 b$.

Tipper, E. T., Galy, A., and Bickle, M. J.: Calcium and magnesium isotope systematics in rivers draining the Himalaya-Tibetan-plateau region: Lithological or fractionation control?, Geochim. Cosmochim. Ac., 72, 1057-1075, doi:10.1016/j.gca.2007.11.029, 2008.

Tipper, E. T., Gaillardet, J., Louvat, P., Campas, F., and White, A. F.: Mg isotope constraints on soil pore-fluid chemistry: Evidence from Santa Cruz, California, Geochim. Cosmochim. Ac., 74, 3883-3896, doi:10.1016/j.gca.2010.04.021, 2010.

Tooth, A. F. and Fairchild, I. J.: Soil and karst aquifer hydrological controls on the geochemical evolution of speleothem-forming drip waters, Crag cave, southwest Ireland, J. Hydrol., 273, 51-68, 2003.

Tremaine, D. M., Froelich, P. N., and Wang, Y.: Speleothem calcite farmed in situ: Modern calibration of $\delta^{18} \mathrm{O}$ and $\delta^{13} \mathrm{C}$ paleoclimate proxies in a continuously-monitored natural cave system, Geochim. Cosmochim. Ac., 75, 4929-4950, doi:10.1016/j.gca.2011.06.005, 2011.

Trouet, V., Esper, J., Graham, N. E., Baker, A., Scourse, J. D., and Frank, D. C.: Persistent positive North Atlantic Oscillation mode dominated the Medieval Climate Anomaly, Science, 324, 78-80, doi:10.1126/science.1166349, 2009.

van Breukelen, M. R.: Peruvian stalagmites as archives of Holocene temperature and rainfall variability, Ph.D.thesis, Vrije Universiteit Amsterdam, The Netherlands, Amsterdam, 208 pp., 2009.

van Breukelen, M. R., Vonhof, H. B., Hellstrom, J. C., Wester, W. C. G., and Kroon, D.: Fossil dripwater in stalagmites reveals Holocene temperature and rainfall variation in Amazonia, Earth Planet. Sci. Lett., 275, 54-60, doi:10.1016/j.eps1.2008.07.060, 
2008.

Verheyden, S., Genty, D., Deflandre, G., Quinif, Y., and Keppens, E.: Monitoring climatological, hydrological and geochemical parameters in the Père Noël cave (Belgium): Implication for the interpretation of speleothem isotopic and geochemical time-series, Int. J. Speleol., 37, 221-234, 2008.

Vollweiler, N., Scholz, D., Mühlinghaus, C., Mangini, A., and Spötl, C.: A precisely dated climate record for the last $9 \mathrm{kyr}$ from three high alpine stalagmites, Spannagel cave, Austria, Geophys. Res. Lett., 33, L20703, doi:10.1029/2006GL027662, 2006.

Wassenburg, J. A., Immenhauser, A., Richter, D. K., Jochum, K. P., Fietzke, J., Goos, M., Scholz, D., and Sabaoui, A.: Climate and cave control on Pleistocene / Holocene calcite-toaragonite transitions in speleothems from Morocco: Elemental and isotopic evidence, Geochim. Cosmochim. Ac., 92, 23-47, doi:10.1016/j.gca.2012.06.002, 2012.
White, W. B.: Paleoclimate records from speleothems in limestone caves, in: Studies of cave sediments, edited by: Sasowasky, I. D. and Mylroie, J., Kluwer, New York, 135-176, 2004.

Williams, P. W., King, D. N. T., Zhao, J. X., and Collerson, K. D., Speleothem master chronologies: combined Holocene ${ }^{18} \mathrm{O}$ and ${ }^{13} \mathrm{C}$ records from the North Island of New Zealand and their palaeoenvironmental interpretation, The Holocene, 14, 194-208, 2004.

Xoplaki, E., Luterbacher, J., Paeth, H., Dietrich, D., Steiner, N., Grosjean, M., and Wanner, H.: European spring and autumn temperature variability and change of extremes over the last half millennium, Geophys. Res. Lett., 32, L15713, doi:10.1029/2005GL023424, 2005.

Young, E. D. and Galy, A.: The isotope geochmistry and cosmochemistry of Magnesium, Rev. Mineral. Geochem., 55, 197-230, 2004. 